\title{
ESTIMATIVA DO NÍVEL DE DANO DE Orthezia praelonga DOUGLAS, 1891 E DE Leucoptera coffeella (GUÉRIN-MÈNEVILLE, 1842) POR VARÍA VEIS FISIOLÓGICAS VEGETAIS
}

\author{
ADEMIR DINIZ NEVES
}

Dissertação apresentada à Escola Superior de Agricultura "Luiz de Queiroz", Universidade de São Paulo, para obtenção do título de Mestre em Ciências, Área de Concentração: Entomologia.

P I R A C I C A B A

Estado de São Paulo - Brasil

Novembro - 2004 


\title{
ESTIMATIVA DO NÍVEL DE DANO DE Orthezia praelonga DOUGLAS, 1891 E DE Leucoptera coffeella (GUÉRIN-MÈNEVILLE, 1842) POR VARÍA VEIS FISIOLÓGICAS VEGETAIS
}

\author{
ADEMIR DINIZ NEVES
}

Engenheiro Agrônomo

\section{Orientador: Prof. Dr. JOSÉ ROBERTO POSTALI PARRA}

\author{
Dissertação apresentada à Escola Superior de \\ Agricultura "Luiz de Queiroz", Universidade de São \\ Paulo, para obtenção do título de Mestre em \\ Ciências, Área de Concentração: Entomologia.
}

P I R A C I C A B A

Estado de São Paulo - Brasil

Novembro - 2004 


\section{Dados Internacionais de Catalogação na Publicação (CIP) DIVISÃO DE BIBLIOTECA E DOCUMENTAÇÃO - ESALQ/USP}

\section{Neves, Ademir Diniz}

Estimativa do nível de dano de Orthezia praelonga Douglas, 1891 e de Leucoptera coffeella (Guérin-Mèneville, 1842) por variáveis fisiológicas vegetais / Ademir Diniz Neves. - - Piracicaba, 2004.

76 p. : il.

Dissertação (Mestrado) - - Escola Superior de Agricultura Luiz de Queiroz, 2004.

Bibliografia.

1. Bicho-mineiro 2. Café 3. Cochonilha-branca 4. Condutância estomática 5. Fotossíntes 6. Limão 7. Manejo integrado 8. Temperatura I. Título

CDD 633.73 
Aos meus pais,

\section{Aparecida Machado e \\ Salustiano Neves (em memória)}

Que com amor e dedicação, me ensinaram e apoiaram em todos os momentos;

A namorada,

\section{Flavia}

Pelo apoio e carinho

...e a você minha filha,

\section{Victória Maria,}

Que com um sorriso ilumina o dia e me faz querer ser um homem melhor, 


\section{AGRADECIMENTOS}

À Escola Sup erior de Agricultura "Luiz de Queiroz", Universidade de São Paulo, por possibilitar a realização desse trabalho.

Ao Prof. Dr. José Roberto Postali Parra pela orientação, incentivo e confiança na realização dessa pesquisa.

Ao Prof. Ricardo Ferraz de Oliveira, do Departamento de Ciências Biológicas, na orientação e auxílio nos trabalhos de fisiologia vegetal.

Aos meus irmãos Ana, Railda, Cida, Alípio, Raildo, Plínio, as cunhadas Júlia e Sueli, ao cunhado Reinaldo e os sobrinhos Vítor Perna e Ana Júlia pela estrutura familiar que me deram.

Aos irmãos de república Alexandre Açauto e Alexandre Xifinho.

Aos Professores Celso Omoto e João Roberto Spotti Lopes pelo incentivo no início de tudo.

Aos demais professores do Programa de Pós-graduação em Entomologia pelos ensinamentos transmitidos e ajuda concedida.

Aos colegas de curso pelo convívio e estudos compartilhados.

A CAPES, pela concessão da bolsa de estudo.

Aos Engenheiros Agrônomos Dori Edson Nava e José Maurício Simões Bento (agora Prof. Maurício) pelas alegrias e trabalhos proporcionados.

A Ana Gabriela Brancalhão pelo inestimável serviço como secretária do programa e pela simpática companhia como pessoa.

Ao Engenheiro Agrônomo Marcelo Oliveira Garcia pela divisão na criação de cochonilhas e amizade desde a graduação. 
Aos professores Murilo Melo e Lázaro Eustáquio Pereira Perez, pela amizade e sugestões feitas durante a realização deste trabalho.

Aos funcionários do Departamento de Entomologia, Tutu, Dino, Vítor e Carlinhos que de alguma forma colaboraram para a realização desse trabalho.

Aos funcionários e alunos do Departamento de Ciências Biológicas, que me receberam cordialmente durante esse trabalho.

A Fischer Agropecuária SA pelo fornecimento constante de mudas de citros.

A Garcafé - Cooperativa dos Cafeicultores de Garça e Região - pelo fornecimento de mudas de café.

Aos colegas do Laboratório de Biologia de Insetos, Negri, Ana, Sandra, Priscila, Mariuxi, Patrícia Milano, Gilberto Picasso, Adriana, Nívia, Flávia Bento, Danilo, André Sinhá e André Bacalhau, Daniel Clone, Cristiane Nardi, Erich, Paulinho, Dori, Maurício, Gabriela Díez-Rodrigues, e em especial a Neide pela troca de receitas e conversas.

Aos amigos da APG-ESALQ, Cláudia, Edmilson, Laércio, Élio, Henrique, Eduardo e Aelson pela batalha diária no fortalecimento cada vez maior da pósgraduação.

A galera do futebol pela descontração e amizade.

E a todos que de alguma forma contribuíram para a realização deste trabalho 


\section{SUMÁRIO}

\section{Página}

RESUMO............................................................................... vii

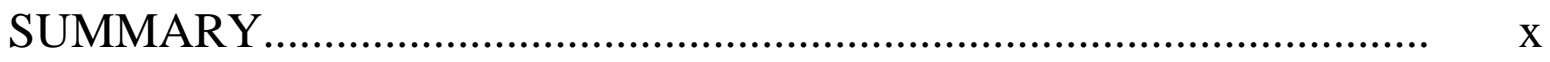

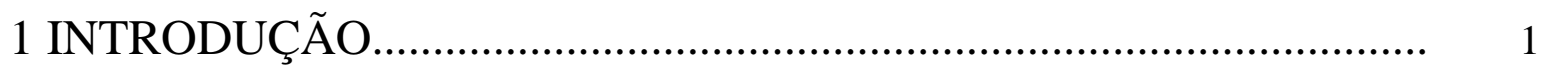

2 REVISÃO DE LITERATURA...........................................................

2.1 O bicho-mineiro Leucoptera coffeella (Guérin-Mèneville, 1842)....... 3

2.2 A cochonilha ortézia - Orthezia praelonga Douglas, 1891.................. 7

2.3 O Estresse de Plantas e Métodos Convencionais de Estimativas de

Controle................................................................................... 13

2.4 Métodos Fisiológicos para Estimativa de Nível de Controle................ 17

3 MATERIAL E MÉTODOS............................................................... 22

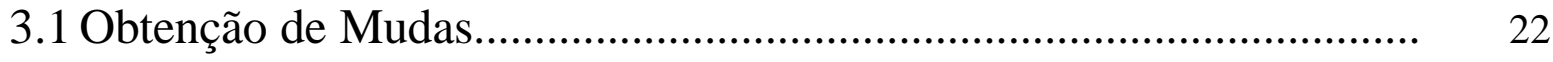

3.1.1 Obtenção de mudas de café 'Obatã' .......................................................... 22

3.1.2 Obtenção de mudas de limão cravo (Citrus limonia L)...................... 22

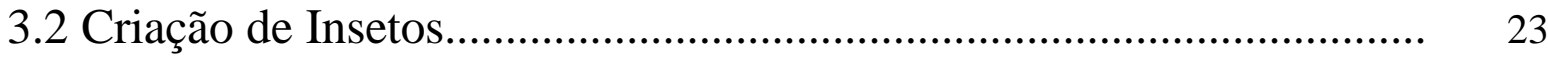

3.2.1 Criação de bicho mineiro (L. coffeella) ................................................. 23

3.2.2 Criação de $O$. praelonga.................................................................. 23

3.3 Medição de Fotossíntese, condutância estomática, transpiração foliar, concentração interna de $\mathrm{CO}_{2}$ e temperatura foliar em folhas de limão cravo atacadas por $O$. praelonga, e em folhas de cafeeiro 'Obatã' atacadas por $L$. coffeella...... 
3.4 Delineamento Estatístico.......................................................................... 27

4 RESULTADOS E DISCUSSÃO......................................................... 30

4.1 Medição de Fotossíntese, condutância estomática, transpiração foliar, concentração interna de $\mathrm{CO}_{2}$ e temperatura foliar em folhas de limão cravo atacadas por $O$. praelonga, e em folhas de cafeeiro 'Obatã' atacadas por L. coffeella ...................................................... 30

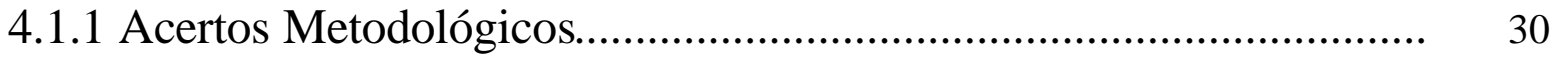

4.1.2 Avaliações da fotossíntese.................................................................

4.1.3 Condutância estomática.................................................................... 39

4.1.4 Transpiração foliar........................................................................

4.1.5 Temperatura Foliar........................................................................ 46

4.1.6 Concentração interna de $\mathrm{CO}_{2}$, eficiência instantânea de carboxilação e eficiência intrínseca do uso da água......................... 48

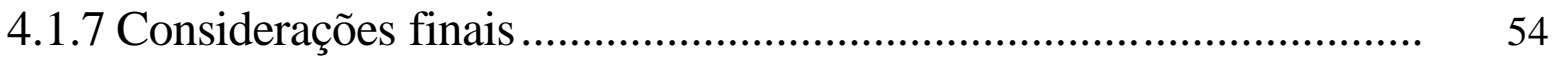

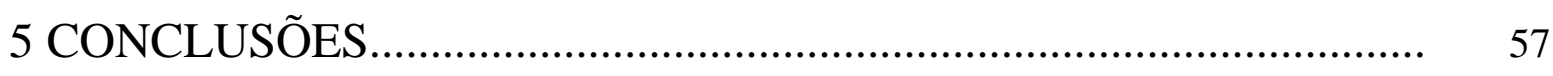

REFERÊNCIAS BIBLIOGRÁFICAS................................................... 58 


\title{
ESTIMATIVA DO NÍVEL DE DANO DE Orthezia praelonga DOUGLAS, 1891 E DE Leucoptera coffeella (GUÉRIN-MÈNEVILLE, 1842) POR VARÍAVEIS FISIOLÓGICAS VEGETAIS
}

\author{
Autor: ADEMIR DINIZ NEVES \\ Orientador: Prof. Dr. JOSÉ ROBERTO POSTALI PARRA
}

\section{RESUMO}

O objetivo do trabalho foi avaliar, por meio de variáveis fisiológicas vegetais como fotossíntese, condutância estomática, transpiração foliar, concentração interna de $\mathrm{CO}_{2}$ e temperatura foliar, o efeito de insetos pragas de diferentes hábitos alimentares em suas plantas hospedeiras. Foram estimados os níveis de dano de um sugador, Orthezia praelonga Douglas, 1891, em limão cravo (Citrus limonia L.), e de Leucoptera coffeella (Guérin-Mènevile, 1842), um mastigador, em mudas de café 'Obatã'. Os ensaios foram realizados em condições ótimas de temperatura, com luz e $\mathrm{CO}_{2}$ saturantes, e diferentes porcentagens de área foliar lesionada, obtidas pela variação do número de insetos por folha, no caso de $O$. praelonga em limão cravo (de 0 a 35 cochonilhas/folha (0-6\%), de 40 
a 70 cochonilhas/folha (7-13\%), de 80 a 220 cochonilhas/folha (14-40\%) e >220 cochonilhas/folha $(>40 \%)$ ) ou por tecido vegetal consumido (intervalos de $025 \%$, 26$36 \%$ e $>37 \%$ ), no caso de L. coffeella em mudas de cafeeiro. As leituras das variáveis fisiológicas vegetais foram feitas com um medidor portátil de fotossíntese (IRGA). Os dados foram analisados por meio de uma regressão não linear, e, nos dois casos, existe uma correlação negativa entre fotossíntese e área foliar lesionada, ou seja, quanto maior a área foliar lesionada, menor a fotossíntese; e o ponto de inflexão negativo da curva, no qual um pequeno aumento na área foliar lesionada resultou em uma grande perda fotossintética, é tomado como referência de nível de dano, sendo que o nível de controle destas pragas, esta abaixo destes valores. A condutância estomática, a transpiração foliar, a concentração interna de $\mathrm{CO}_{2}$ e a temperatura foliar, em ambos os casos, não demonstram uma correlação definida com a intensidade de danos. A transpiração foliar em limão cravo atacado por $O$. praelonga é maior nos pontos onde também é maior a condutância estomática, e nas folhas de café com ataque de L. coffeella a transpiração foliar mantem-se constante durante toda a curva, semelhante à variável condutância estomática.. As relações matemáticas de fotossíntese/concentração interna de $\mathrm{CO}_{2}$, e fotossíntese/condutância estomática são, em ambos os casos, decrescentes, o que demonstra respectivamente queda na eficiência instantânea de carboxilação da rubisco e redução da eficiência intrínseca do uso da água em função do aumento da área foliar lesionada. A análise conjunta dos dados demonstrou que $O$. praelonga afeta o fotossistema I (PS I) de folhas de Imão cravo; enquanto L. coffeella afeta, em primeiro plano, o fotossistema II (PS II). No caso de $O$. praelonga em limão cravo, determina-se a faixa de 7 a $13 \%$ de área foliar lesionada (de 40 a 70 cochonilhas/folha) como sendo o valor de nível de dano, e para L. coffeella em cafeeiro este valor ficou na faixa de 25 a $36 \%$ de área foliar lesionada (tecido consumido pelo inseto). Os valores obtidos em laboratório, necessitam ajustes efetivos na determinação do nível de controle destas pragas no campo. A técnica de leitura de fotossíntese mostrourse adequada a este propósito, e a análise dessa variável demonstrou ser a melhor opção para tal correlação. 


\section{DAMAGE ESTIMATE OF Orthezia praelonga DOUGLAS, 1891 AND Leucoptera coffeella (GUÉRIN-MÈNEVILLE, 1842) BY PLANT PHYSIOLOGICAL VARIABLES}

Author: ADEMIR DINIZ NEVES

Adviser: Prof. Dr. JOSÉ ROBERTO POSTALI PARRA

\section{SUMMARY}

The goal of this work was to evaluate the effect of insect pests of different feeding habits in their host plants through readings of plant physiological variables as photosynthesis, stomatal conductance, leaf transpiration, internal carbon dioxide concentration and leaf temperature. Thus, one estimated the injury level of a sucking insect, Orthezia praelonga Douglas, 1891, in 'Rangpur' lime (Citrus limonia L.), and Leucoptera coffeella (Guérin-Mènevile, 1842), a chewing insect, in 'Obatã' coffee seedlings. The trials were carried out under optimum temperature conditions, with saturating light and $\mathrm{CO}_{2}$, with different injured leaf area percentages, obtained by the 
variation of the number of insects per leaf, in the case of $O$. praelonga in 'Rangpur' lime (0-35 mealybugs/leaf (0-6\%), 40-70 mealybugs/leaf (7-13\%), 80-220 mealybugs/leaf (14$40 \%$ ), and $>220$ mealybugs/leaf $(>40 \%)$ ), or through plant tissue consumed $(0-25 \%, 26-$ $36 \%$ and $>37 \%$ intervals), in the case of L. coffeella in coffee seedlings. Plant physiological variables readings were performed through a portable photosynthesis meter (IRGA). The data were analyzed by means of nonlinear regression, and, in both cases, a negative correlation was observed between photosynthesis and the injured leaf area, that is, the larger the injured leaf area, the lesser the photosynthesis; the negative inflection point of the curve, upon which a slight increase in the injured leaf area resulted in great photosynthesis loss is taken as a damage level reference, and the control level of these pests is below these values. The stomatal conductance, leaf transpiration, internal $\mathrm{CO}_{2}$ concentration and the leaf temperature, in both cases, showed no defined correlation with the damage intensity. The leaf transpiration in 'Rangpur' lime attacked by $O$. praelonga is higher in points where the stomatal conductance is higher as well, and in coffee leaves attacked by L. coffeella the leaf transpiration remains constant throughout the curve, similarly to the stomatal conductance variable. The mathematical relationships of photosynthesis/internal $\mathrm{CO}_{2}$ concentration, and photosynthesis/stomatal conductance are, in both cases, decreasing, which respectively shows drop in instant Rubisco carboxylation efficiency and reduction of the intrinsic efficiency of water use according to the increase of the injured leaf area. The joint data analysis showed that $O$. praelonga affects photosystem I (PS I) of 'Rangpur' lime, while L. coffeella affects, at first, photosystem II (PS II). In the case of $O$. praelonga in 'Rangpur' lime the 7-13\% range of the injured leaf area (40-70 mealybugs/leaf) is determined as the damage level value, and for L. coffeella in coffee the value ranges $25-36 \%$ of the injured leaf area (tissue consumed by the insect). The values found in laboratory require field validation for effective adjustments to determine the level to control these insect pests. Overall, the photosynthesis reading technique was shown adequate to this purpose, and the analysis of this variable was the best choice for such correlation. 


\section{INTRODUÇÃ̃O}

O Manejo Integrado de Pragas (MIP) prevê um sistema de decisão de uso de táticas de controle, isoladas ou associadas harmoniosamente, numa estratégia de manejo, baseando-se em análises de custo/benefício que levam em conta o interesse e/ou impacto nos produtores, sociedade e ambiente (fatores econômicos, ecológicos e sociais) (Kogan, 1998). O manejo integrado tem como base a identificação das pragas, o conhecimento dos seus inimigos naturais, que são responsáveis pela manutenção do equilíbrio (mortalidade natural no ecossistema) dos insetos-pragas, além da amostragem de pragas para determinar o respectivo nível de controle (Gonzales, 1971, adaptado por Zucchi, 1990).

Neste sentido, é necessário não só o conhecimento da praga, mas também a interação dinâmica com seus hospedeiros e o ambiente, envolvendo ações inter e multidisciplinares.

Em geral, o nível de controle é determinado simulando-se os danos, definindose valores, baseando-se no número de insetos ou área foliar lesionada, a partir dos quais haverá redução na produção.

Na maioria dos casos, tais níveis de controle são estimados diretamente, sendo poucos os casos em que tal determinação é feita indiretamente, avaliando-se fatores ligados à planta (Loayza, 1999; Neves et al., 2001).

Assim, para pragas (insetos e ácaros) praticamente inexistem trabalhos que estimem o nível de controle com base em medições de variáveis fisiológicas vegetais, como a fotossíntese, por exemplo.

Assim, a presente pesquisa tem por objetivo avaliar o nível de dano para dois insetos de hábitos alimentares diferentes, um mastigador, o bicho-mineiro do cafeeiro, 
Leucoptera coffeella (Guérin-Mèneville, 1842), e um sugador, a cochonilha Orthezia praelonga Douglas, 1891, em citros, através da medição da fotossíntese, condutância estomática e transpiração foliar, concentração interna de $\mathrm{CO}_{2}$ e temperatura foliar, ou seja, variáveis fisiológicas vegetais.

São duas pragas importantes, sendo a primeira delas, L. coffeella, praga de origem africana e relatada no Brasil desde 1851 (Taunay, 1943) e que hoje em dia é a principal praga dos cafeeiros e também a de maior disseminação no globo, responsável por prejuízos da ordem de $50 \%$ na produção (Reis \& Souza, 1996), e, a segunda, O. praelonga, de origem neotropical e relatada no Brasil desde o início do século XX, uma das mais importantes pragas da citricultura nos últimos anos (Cassino et al., 1993) e que em alguns casos chega a causar grandes perdas nos pomares cítricos.

São analisadas as alterações nos processos fisiológicos vegetais em função de diferentes níveis de infestação, estimando-se o nível de dano a partir destas alterações no cafeeiro e em citros. 


\section{REVISÃO DE LITERATURA}

\subsection{O bicho-mineiro, Leucoptera coffeella (Guérin-Mèneville, 1842)}

O bicho-mineiro, Leucoptera coffeella (Guérin-Mèneville, 1842) (Lepidoptera - Lyonetiidae) é a principal praga dos cafeeiros brasileiros e, chega, em determinadas situações a causar prejuízos da ordem de 50\% (Reis \& Sousa, 1996). É mais problemático em cafezais novos ou mais espaçados, aparecendo com maior intensidade em condições antagônicas àquelas que favorecem a ferrugem e a broca-do-café, desde que estes últimos preferem cafezais adensados e microclima mais úmido (Parra, 1975).

A grande dificuldade de controle do bicho mineiro é a determinação do seu nível de dano econômico, sendo que, tal controle, é feito preventivamente, seja através de granulados sistêmicos (na época chuvosa) ou através de pulverizações com fosforados ou piretróides (em época seca), aplicações estas que acarretam o desequilíbrio no agroecossistema favorecendo o ataque de ácaros ou outras pragas (Reis \& Souza, 1996).

Praga de origem africana, especificamente da Abissínia (Parra, 1975), foi constatada no Brasil a partir de 1851 (Taunay, 1943), proveniente, provavelmente, de mudas de café vindas das Antilhas e da Ilha de Bourbon (Fonseca, 1949), sendo que atualmente encontra-se difundida por todas as regiões cafeeiras do país, além de muitos

países das Américas e África; de hábito monófago é, possivelmente, a praga cafeeira de maior disseminação no mundo.

$\mathrm{Na}$ fase adulta é uma mariposa de cerca de $6,5 \mathrm{~mm}$ de envergadura e 2,2 $\mathrm{mm}$ de comprimento, de coloração branco-prateado, com as extremidades das asas anteriores 
apresentando faixas amarelas orladas de preto e uma mancha ocelar também preta. Durante o dia, os adultos escondem-se na folhagem inferior da copa, procurando ambientes de microclima mais úmido, sendo que no crepúsculo, as fêmeas realizam a postura na parte adaxial das folhas; cada mariposa põe, em média 56,6 ovos a $27^{\circ} \mathrm{C}$, sendo que o período de oviposição varia de 3 a 18 dias, sendo os ovos colocados de forma individualizada (Parra, 1985).

O desenvolvimento larval varia de 9 a 26 dias, de acordo com a temperatura (Parra, 1975), onde a larva ao eclodir passa diretamente para o mesofilo foliar, aonde irá se alimentar até a fase de pré-pupa. É comum as lesões coalescerem e conterem mais de uma lagarta por mina (lesão) (Figura 01).

A pupação ocorre eventualmente no solo, ou na parte abaxial das folhas na porção inferior da copa, sendo que a cobertura morta ('mulching') favorece a pupa, que é facilmente reconhecida pelos fios sedosos e brancos trançados na forma de X.

O dano ocasionado à cultura é devido à redução de área fotossintética e senescência precoce e queda das folhas, e os prejuízos podem ser notados na safra seguinte.

A lagarta se alimenta exclusivamente do parênquima paliçádico (Cárdenas Murillo \& Orozco Castaño, 1983; Ramiro et al. 2003) e a epiderme superior do tecido atacado sofre necrose, adquirindo uma coloração amarela pardacenta, sendo comum a sua ruptura expondo a mina e excrementos da lagarta, e constituindo-se assim em porta de entrada a outros organismos fitopatogênicos (Cárdenas Murillo \& Orozco Castaño, 1983).

Guerreiro Filho \& Mazzafera (2000) relataram que o principal alcalóide produzido pelas plantas de café, a cafeína, não produz nenhum tipo de efeito sobre a oviposição de L. coffeella ou mesmo no desenvolvimento das lagartas, indicando uma adaptação coevolutiva, sem prejudicar portanto, o desenvolvimento do inseto.

Nantes (1977) avaliando a biologia e danos de bicho-mineiro em três variedades distintas de café relatou o consumo larval como sendo de 1,15; 1,36 e 1,0 $\mathrm{cm}^{2}$ em 'Catuaí', 'Mundo Novo' e 'Icatu', respectivamente. 
Os prejuízos causados pelo bicho mineiro variam de acordo com a intensidade, duração e fase fenológica do ataque, variando de 37\%, 53\% e até $80 \%$ de perda de capacidade produtiva em São Paulo, Minas Gerais e Espírito Santo, respectivamente.

Parra (1975) verificou que na fase preparativa do cafeeiro (julho) uma redução de 25, 50 e 75\% na área foliar do cafeeiro, cultivar Mundo Novo, provocou prejuízos na produção de 9, 24 e 87\% respectivamente. Porém, na fase construtiva (no vembro) essas mesmas reduções na área foliar resultaram danos na produção de 39, 43 e 46\%. Estes dados indicam a necessidade de amostragens diferenciais para cada época, a fim de se determinar o nível de controle da praga em cada situação. Este é o único trabalho de determinação de nível de controle da praga, embora de forma simulada, mostrando que na fase construtiva do cafeeiro, as perdas são 4 vezes maiores do que na fase preparativa desta rubiácea.

O bicho mineiro, L. coffeella é uma praga que possui um grande número de inimigos naturais, entre parasitóides e predadores, sobretudo vespas e outros artrópodes, sendo importante conhecer a interação destes organismos com a praga para a otimização de planos de amostragens e táticas de controle. Neste aspecto Tozatti \& Gravena (1988) apontaram como fator chave de mortalidade larval desta praga a predação por vespas e em segundo plano a ação de parasitóides, sobretudo da fimília Eulophidae. Reis Jr (1999) apontou a ocorrência de interação antagônica de vespas e parasitóides, indicando que a competição entre estes agentes de controle biológico leva a predação por vespas de grande número de lagartas já parasitadas. 


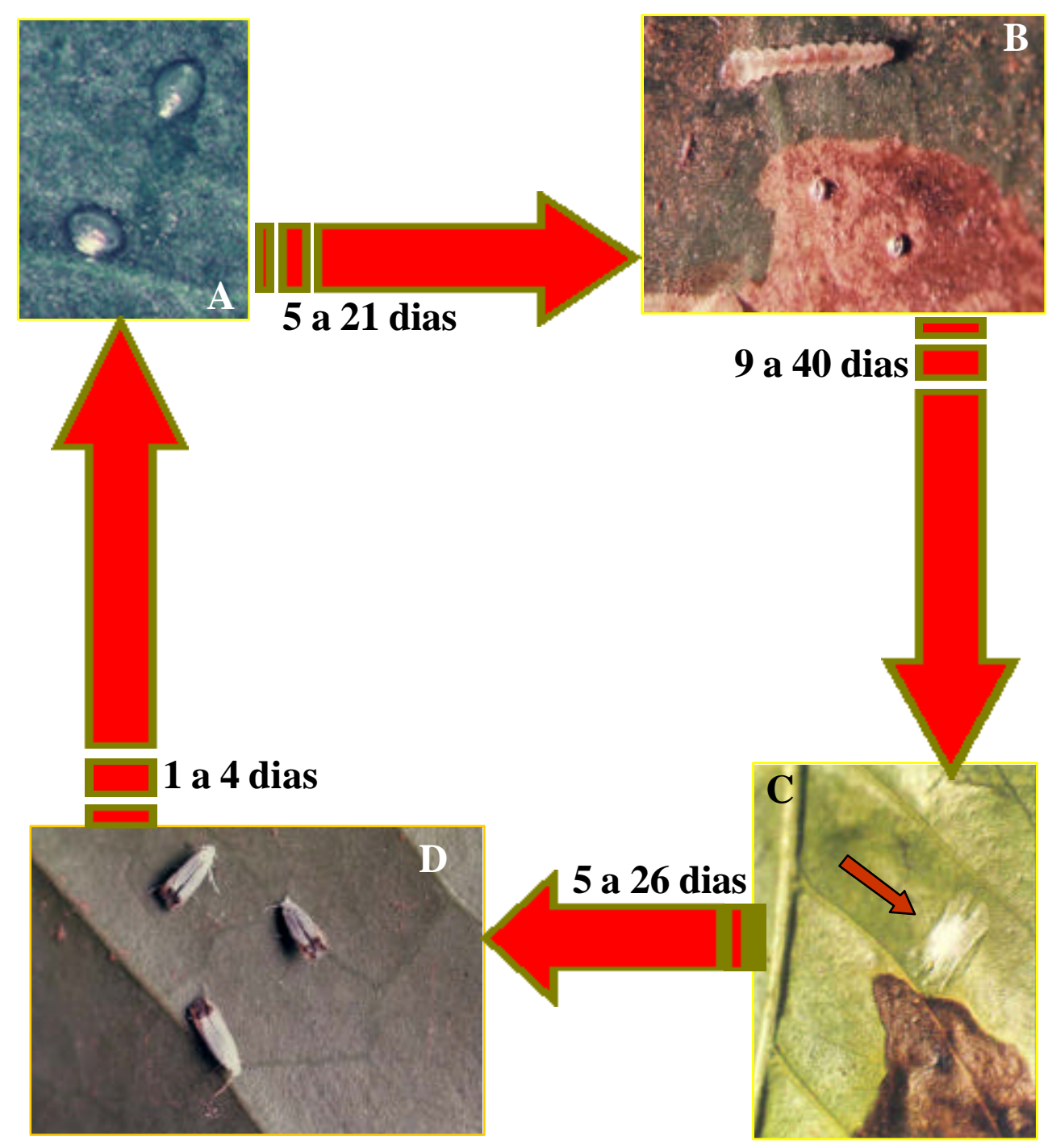

Figura 1 - Ciclo biológico e danos de L. coffeella: ovo (A), lagarta (B), pupa (C) e adulto (E) (Adaptado de Parra, 1985 e Gallo et al., 2002) 


\subsection{A cochonilha ortézia - Orthezia praelonga Douglas, 1891}

A cochonilha, Orthezia praelonga Douglas, 1891 (Hemiptera: Ortheziidae) chamada vulgarmente de "piolho branco" é originária da região tropical americana, onde é constantemente referida como infestante de plantas silvestres e ornamentais (Rosamiglia, 1998). O primeiro registro de ocorrência desta cochonilha no Brasil foi em 1938, em Pernambuco (Pyenson, 1938 referido em Kogan, 1964); Costa Lima (1942) já alertava que esta poderia se tornar uma praga de importância agrícola, sendo constatada no Rio de Janeiro em 1947 (Gonçalves \& Cassino, 1978), e desde 1954 é considerada praga de importância econômica para a citricultura carioca, causando prejuízos da ordem de 50 a 90\% na baixada fluminense (Nascimento, 1980). Vasconcellos et al. (1980) relataram que $O$. praelonga constitui-se em uma das principais pragas da citricultura fluminense, não somente pelos prejuízos causados, mas também por levar o agricultor ao desestímulo e abandono do pomar.

Devido ao fato de suportar grandes variações climáticas e a ausência de barreiras orográficas, Puzzi \& Camargo (1963) consideraram a possibilidade de que $O$. praelonga tornar-se-ia uma praga importante nas zonas citrícolas do Estado de São Paulo e o Vale do Paraíba seria uma via natural de entrada do inseto, baseando-se em estudos de climogramas do Rio de Janeiro e da região de Limeira, SP.

A cochonilha chegou a São Paulo somente em 1978, no município de Severínia (Gonçalves \& Cassino, 1978); atualmente está disseminada na maioria dos municípios que cultivam citros nos Estados de São Paulo (Prates \& Pinto, 1987), Rio de Janeiro e Sergipe de acordo com levantamentos realizados pela Embrapa Meio Ambiente, Secretaria de Agricultura do Estado de São Paulo e Coordenadoria de Assistência Técnica Integral (CATI). Teixeira et al. (2001) apontaram ainda a disseminação da cochonilha nos Estados da Bahia, Rio Grande do Sul, Pará e Pernambuco, e em função do grande número de plantas hospedeiras e da alta capacidade de reprodução, projeta-se como séria ameaça à citricultura do Nordeste brasileiro (Carvalho et al. 1998). 
Tamai et al. (2000) salientaram que em floricultura o controle de $O$. praelonga deve se feito com rigor, uma vez que lotes que apresentam danos ou presença da praga são depreciados no momento de comercialização.

Benvenga et al.(2001) (referido por Prates et al., 2002) relataram que esta cochonilha se tornou uma praga chave na cultura dos citros devido à dificuldade de controle, de visualização do foco inicial de ataque e rápida dispersão.

A temperatura ótima de desenvolvimento desta praga encontra-se na faixa de $25^{\circ} \mathrm{C}$, porém é nos meses mais frios e secos do ano, com menor precipitação pluviométrica e menor umidade relativa do ar, que sua incidência é mais intensa (Prates \& Pinto, 1987); no entanto, na região de Itapólis - SP, a ocorrência da praga fugiu aos padrões habituais e já se manifesta também na época de início das chuvas de verão (Fundecitrus, 2003). Gomes (1954) e Viegas et al. (1995) relataram que na época de maior temperatura e umidade as populações desta praga sofrem decréscimo em função da ação de agentes de controle natural, especialmente fungos.

As fêmeas possuem cerca de $2,5 \mathrm{~mm}$, têm o corpo ovalado, com coloração esverdeada, coberta por placas de cera branca, sendo que duas placas salientes cobrem a cabeça na parte posterior do corpo; possuem a capacidade de colocar mais de 100 ovos ao longo de sua vida, sendo que estes ficam protegidos em uma estrutura formada pela união de bastonetes alongados de cera, de coloração branca e com uma curvatura acentuada para cima situada na parte traseira de seu corpo e chamado de ovissaco, com o qual a fêmea pode atingir 4,5 mm de comprimento (Suplicy Filho et al., 1983). As ninfas também permanecem no ovissaco até a primeira ecdise, e esta característica dificulta o seu controle (Lima, 1981; Nascimento et al., 1993) (Figura 2).

Os machos diferem das fêmeas em cor e tamanho, sendo menores e apresentando duas asas e uma cauda longa, formada por fios de cera, sendo que quando ninfas são semelhantes nos três primeiros ínstares; a partir do segundo ínstar, se dirigem ao tronco, galhos ou solo onde permanecem reunidos em colônia e evoluem para uma fase intermediária, semelhante a um pupário envolvido por inúmeros filamentos de cera, de onde emergem os adultos. 
Cada inseto tem um período de vida entre 40 e 200 dias (dado este discutível e sem consenso entre pesquisadores), durante o qual suga de maneira contínua a seiva das plantas. Os danos são referentes à diminuição da área fotossintética, uma vez que o inseto, em colônia, cobre uma grande área foliar. Ocorre também o dano pela introdução do aparato bucal da cochonilha na planta, causando rompimento de vasos e células, além de propiciar a entrada de outros organismos fitopatogênicos. A inserção do aparato bucal e sucção contínua de seiva promove a injeção de toxinas provenientes da saliva do inseto, num processo de fitotoxemia (Leite \& Pascholati, 1995), que acarreta a desfolha da planta, enfraquecimento das árvores e queda dos frutos (mais de 50\%), sendo que os restantes ficam "aguados", com baixo teor de açúcar e acidez titulável, e em casos extremos, os frutos ficam muito pequenos e imprestáveis para o comércio (Teixeira et al, 2001).

A cochonilha provoca ainda um dano indireto, porém intenso, que é a presença do fungo Capnodium sp. (Figura 2D e E), conhecido como fumagina (Gomes, 1954), que se forma no material açucarado exsudado pela cochonilha ("honeydew") e que afeta a fotossíntese e transpiração das plantas (Robbs, 1947; Lima, 1981; Prates, 1987; Cassino et al., 1991 e 1993; Nascimento et al., 1993 e Guirado et., 2001).

A cochonilha tem sua sobrevivência favorecida por possuir um grande número de hospedeiros alternativos como Coleus sp., Acalypha sp., Hibiscus sp., camarão amarelo, Croton sp. e Bougainvillea sp., além de outras espécies de interesse agrícola e plantas daninhas (Suplicy et al, 1983). Sua dispersão é realizada através de material de colheita, roupas, vento, máquinas e implementos, além de transporte por formigas (Cesnik et al., 2003).

O controle realizado é basicamente de forma preventiva através de organofosforados granulados, ou aplicação de pulverizações de piretróides ou organofosforados, no foco de ataque e num raio de dez plantas vizinhas (Gravena, 1999 e Benvenga et al, 2000 referidos em Prates et al, 2002),sendo que este controle, quando empregado de maneira inadequada, causa a morte dos inimigos naturais, favorecendo a infestação de novas pragas e reinfestação da própria cochonilha. 
As reinfestações de pomares tratados se dão pelo transporte de ninfas de primeiro e segundo ínstares pelo vento, por forésia em dípteros e também pelo próprio movimento do inseto (Lima et al., 1980)

Gravena (2002) preconizou como chave no manejo desta praga o monitoramento realizado por pragueiros, visando identificar o foco inicial e promover o controle através de reboleiras em torno da planta foco. Em casos em que ocorram no talhão mais de duas plantas afastadas entre si e com infestação, opta-se pelo controle com lança chamas no tronco das árvores infectadas para o controle dos machos e aplicação de calda com boveril@, óleo e acefato através de pistolas, ao invés de turboatomizador, em todo talhão para o isolamento do foco. Deve ser realizado um repasse com aldicarb, quinze ou vinte dias depois, para eliminar possíveis ninfas que tenham escapado ao primeiro controle e impedir assim a reinfestação da praga.

Outra opção de controle que vem se tornando bastante freqüente é o uso de isolados de fungos como Beauveria bassiana (Garcia et al. 2000), Cladosporium sp. associados ao uso de óleo mineral, além de outros selecionados como Colletotrichum gloeosporioides e Verticillium lecanii.

Garcia (2004) selecionou entre 50 isolados de oito espécies de fungos entopatogênicos, dois isolados de $V$. lecanii que apresentaram resultados promissores para uso no controle da praga, produzindo índices de 40,5 e 46,6\% de mortalidade da cochonilha

Viegas et al. (1995) identificaram a patogenicidade dos fungos B. bassiana, $C$. gloeosporioides e de Metharizium anisopliae para ninfas de segundo e terceiro ínstares de $O$. praelonga, sendo os dois primeiros os que apresentaram melhores resultados. Em pomares comerciais, Prates (1980) relatou ocorrência de epizotias provocadas por $C$. gloeosporioides, $\quad$ V. lecanii e Cladosporium herbarum var. aphidicola em $O$. praelonga.

Segundo Prates (1980) esta cochonilha ainda possui inúmeros inimigos naturais como Gitona brasiliensis (Lima, 1950) (Diptera: Drosophilidae) e Scymnus sp. Kugelann, 1794 (Coleoptera: Coccinelidae) que predam os ovos ainda no ovissaco; 
predação de jovens e adultos por Ambracius dufourei Stal. (Hemiptera: Miridae), Azya luteipes Mulsant, 1850 (Coleoptera: Coccinelidae) e alguns crisopídeos.

Em estudos de levantamento ecológico de inimigos naturais realizados por Bobadilla et al. (1999) no norte do Chile (Vale do Azapa e Província de Parinacota) foram encontrados: Gitona sp. (Diptera: Drosophilidae), Melaleucopis sp. L. (Diptera: Chamaemyiidae), Hyperaspis annexa Lê Conte e Scymnus sp. (Coleoptera: Coccinelidae) e crisopídeos.

Existe ainda, segundo Nascimento et al., 1993, o caracol rajado Oxystyla pulchella Spix, 1827 que ocorre naturalmente na Bahia e Sergipe e controla de maneira eficiente esta cochonilha, apresentando ainda a vantagem de eliminar a vegetação epífita que serve de refúgio à mesma (Cruz et al., 1999). 


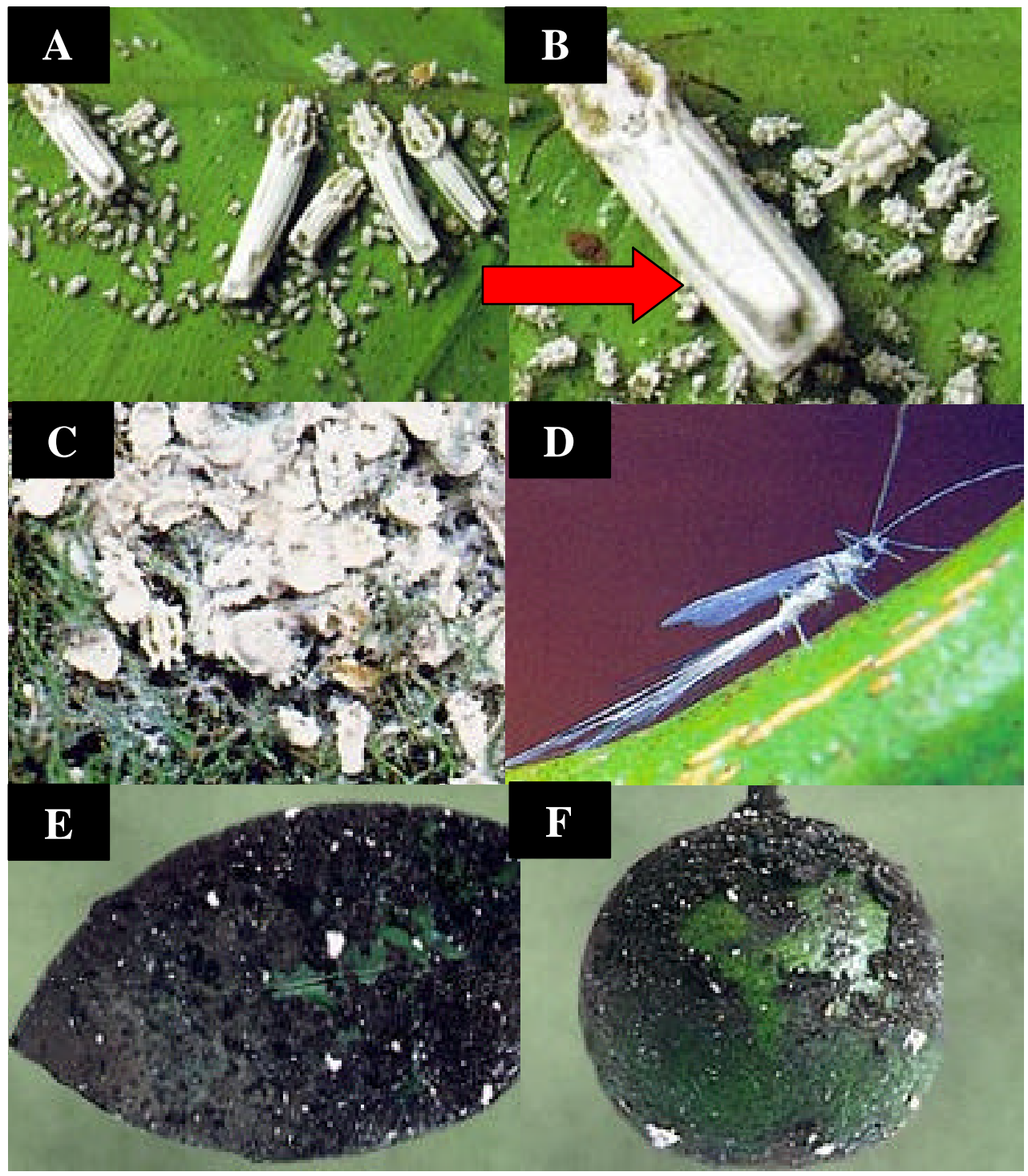

Figura 2 - Orthezia praelonga: fêmea e colônia de ninfas (A), fêmea com destaque para ovissaco (B), pupário de machos (C), macho (D), fumagina na folha (E) e fumagina no fruto ( $F$ ) (Fotos: Fundecitrus, 2004) 


\subsection{O Estresse de Plantas e Métodos Convencionais de Estimativas de Controle}

Fator de estresse de plantas é definido como "qualquer condição desfavorável ou substância que afete ou bloqueie o metabolismo, o crescimento e o desenvolvimento da planta" (Lichtenthaler, 1996). Do ponto de vista botânico, entre as diversas definições existentes, baseando-se em diversas observações em diferentes plantas, Larcher (1987) definiu que o estresse de plantas pode ser considerado como "o estado no qual o aumento da demanda metabólica celular conduz a uma desestabilização inicial das funções, seguida pela normalização e aumento da resistência e se o limite de tolerância for excedido e a capacidade adaptativa exigir esforço extra, o resultado pode ser um dano permanente ou mesmo a morte da planta. Ainda Larcher (1987) relatou que o fator de estresse contém tanto elementos construtivos como destrutivos, sendo este um fator de seleção natural bem como um condutor a aumentar a resistência e adaptação evolutiva dos vegetais.

Lichtenthaler (1988) propôs a extensão do conceito de Larcher em diferenciações entre o 'eu-estresse' ("eu-stress”) e o 'dis-estresse' (“dis-stress”), na qual o estado de 'eu-estresse' é uma ativação ou estimulação com efeitos positivos ao desenvolvimento da planta; por outro lado, o 'dis-estresse' é um estresse verdadeiro na acepção da palavra e que provoca um dano que induz a um efeito negativo no desenvolvimento da planta.

Siedow (1995), presidente da Sociedade Americana de Fisiologia Vegetal, definiu de maneira clara e objetiva que "estresse vegetal se refere a uma ampla escala de fatores biológicos e ambientais aos quais as culturas e outras plantas são submetidas diariamente; entre estes fatores destacam-se o frio, o calor, ervas daninhas, insetos e doenças causadas por vírus, fungos e bactérias".

Neste sentido, o estresse vegetal pode ser dividido em quatro fases distintas: Fase 01 - Fase da Resposta, também definida como 'reação de alarme', é o início do estresse onde ocorre desvio das funções normais, declínio da vitalidade e processos catabólicos excedendo os anabólicos (nesta etapa os processos mais afetados são a fotossíntese, o transporte e acúmulo de metabólitos e/ou elevação da concentração ou 
translocação de íons); Fase 02 - Fase da Restituição, também definida como 'estágio de resistência', no qual ocorre a continuação do estresse e desencadeiam-se processos adaptativos, processos reparatórios e reativação de funções afetadas; Fase 03 - $\underline{\text { Fase }}$ Final, também definida como 'estágio de exaustão', inicia-se com o prolongamento do estresse e resulta em intensidade alta de estresse, sobrecarga da capacidade adaptativa e lesão crônica ou morte de células ou tecidos; Fase 04 - Fase da Regeneração, é o momento em que ocorre a regeneração parcial ou total das funções fisiológicas quando o agente estressor é removido e o dano ainda não é intenso (Lichtenthaler, 1996). Os fatores de estresse podem ainda ser naturais como alta irradiação (fotoinibição, fotooxidação), calor (aumento rápido de temperatura), baixas temperaturas ("chilling"), deficiência hídrica, deficiência natural de minerais, longos períodos de chuva, insetos e vírus, bactérias e fungos fitopatogênicos ou de características antrópicas como uso excessivo de herbicidas, inseticidas (acaricidas) e fungicidas, poluentes atmosféricos, ozônio e formação de tipos de oxigênio altamente reativos (radicais livres), chuvas ácidas, descarga de metais pesados, elevação da radiação UV e aumento acelerado de $\mathrm{CO}_{2}$, promovendo alterações no clima global.

Portanto, necroses foliares, como as causadas por alimentação de lagartas, formas imaturas ou mesmo adultos de insetos em plantas silvestres ou de interesse comercial e que resultem em mudanças adversas na forma, funcionamento ou integridade da planta e possam levar ao dano parcial ou morte da planta ou de suas partes (Agrios, 1997), estão entre os vários fatores de estresse vegetal citados por Lichtenthaler (1996).

Estimativas confiáveis dos prejuízos causados pelos insetos e ácaros são prérequisitos para o desenvolvimento de qualquer programa bem sucedido de controle de pragas (ou doenças), independente do método a ser utilizado (Zadoks \& Schein, 1979). A quantificação de danos é, portanto, um ponto chave na definição de qualquer estratégia ou tática de controle (Bergamin Filho et al., 1995).

Modelos empíricos de danos são comumente usados para estabelecer uma relação entre intensidade de ataque (ou nível de necrose foliar) e redução de produção. Entretanto, tais modelos apresentam a limitação de serem práticos somente para as 
condições específicas em que foram gerados; assim, a mudança no sistema de produção usado o tornaria inadequado. Segundo Waggoner \& Berger (1987), a severidade do ataque depende do estágio fisiológico da planta sendo que, não é considerada a desfolha ou a área foliar total das plantas, ou mesmo o fato de que a produção depende da área foliar sadia, ainda fotossintetizante (Monteith \& Elston, 1983; Squire, 1990) e não da área ocupada pela praga ou doença. Os métodos de quantificação das pragas ou doenças, ao contrário, têm colocado o hospedeiro num segundo plano e privilegiam o agente estressor (Lopes et al., 1994).

Parra (1975) simulou o ataque de bicho mineiro ao cafeeiro por pré-herbivoria mecânica com uso de tesoura, recortando áreas foliares iguais às áreas consumidas pelo inseto e comparando a produção das plantas atacadas (inseto e pré-herbivoria) em relação àprodução de plantas sadias, estabelecendo assim, um modelo empírico de nível de controle para esta praga.

Parra \& Nakano (1976) determinaram o nível de controle de L. coffeella por estimativa da superfície foliar lesionada, e outros autores baseando-se na contagem do número de ovos por folha (Nantes \& Parra, 1977). Este tipo de associação é comumente observado com relação a outras pragas, e o momento (nível) de adoção de controle foi idealizado por Stone \& Pedigo (1972) ao estabelecerem os critérios para cálculo do nível de dano econômico (NDE) de acordo com a equação (1):

$$
\mathrm{NDE}=\frac{\mathrm{C}}{\text { V.I.D.K }}
$$

Em que:

NDE - nível de dano econômico, $\mathrm{C}$ - custo do controle, $\mathrm{V}$ - valor de mercado da cultura, I - injúria causada pela praga, D - perda na colheita $\mathrm{K}$ - eficiência da medida de controle 
Fernandes (2000) ressaltou que a expressão 'nível de dano econômico' pode ser em função de uma possível tradução equivocada do termo inglês 'Economic Injury Level' (EIL), onde escolheurse dano ao invés de injúria para se definir o momento da tomada de decisão, e, que na realidade injúria significa o estímulo que produz mudança anormal no processo fisiológico da planta; por outro lado, dano é a redução quantificada no crescimento, desenvolvimento ou reprodução da planta resultante de injúria. Porém, mais do que uma simples questão de semântica, deve-se compreender que o dano será avaliado durante ou após a colheita (quantificação da perda econômica propriamente dita), momento em que toda e qualquer tomada de decisão de controle já deveria ter sido tomada, sendo então injúria o termo mais adequado para estabelecer este momento; no entanto, o termo NDE se consagrou pelo uso e não convêm alterações neste sentido, optando-se por entender estes termos, como sinônimos.

Villacorta \& Tornero (1982) propuseram um plano de amostragem seqüencial para o bicho-mineiro-do-cafeeiro, em cafeeiros cultivar Mundo Novo, baseados no número de lesões por folha, abrangendo talhões não menores do que 2 hectares e consideraram como nível de dano econômico a média de 2 lesões por folha.

Villacorta \& Wilson (1994) ainda determinaram a amostragem seqüencial desta praga por presença-ausência de lesões, estimando a sua densidade e indicando como nível de ação o limiar de uma lesão por folha.

Oliveira (2003) estudou e definiu a amostragem de bicho-mineiro e suas vespas predadoras para cafeeiros em formação e em produção, amostrando os pares do sexto e quinto nós de ramos plagiotrópicos do terço mediano do dossel da planta, na face leste das plantas, para cafeeiros em formação; e terço mediano e basal de plantas em produção, entre o terceiro e quinto nós, na face oeste; chegando a unidade amostral não inferior a 49 amostras/talhão na fase de formação e não inferior a 60 amostras/talhão na fase de produção, sendo a opção para o controle, de 5 a 24 amostras/talhão com lesões causadas pela praga para tomada de decisão de 7 a 28 amostras/talhão predadas para a tomada de decisão baseada na população do(s) predador(es).

Moreno et al. (2003) e Gontijo et al. (2003) ratificaram que o plano de amostragem seqüencial para $L$. coffeella tem vantagens sobre o plano convencional por 
permitir amostragens mais rápidas, baratas e precisas, fato já exaustivamente demonstrado por outros autores.

Reis \& Souza (1996) em amostragem convencional adotaram como nível de controle em amostragens quinzenais o valor de $30 \%$ de folhas lesionadas isentas de predação ou parasitismo.

Em comparação de nove métodos de amostragens para determinação do índice de infestação do bicho-mineiro-dos-cafeeiro, Atique (1979) sugeriu a utilização da porcentagem de folhas lesionadas em função da facilidade e por proporcionar resultados equivalentes aos obtidos pelo cálculo total de lesões ou de área lesionada, ou mesmo contagem de lagartas vivas ou de lagartas vivas e mortas.

Gravena (1983) retificou como mais prático e rápido o parâmetro de porcentagem de folhas lesionadas em detrimento ao número de lesões por folha, uma vez que a folha minada tende a se desprender prematuramente do ramo em relação à folha sadia do mesmo par; dessa forma, o cálculo de nível econômico não deve ser restrito a área foliar atacada, uma vez que toda a folha estará comprometida, segundo o autor.

Gravena (1984) determinou para esta praga como momento para tomada de decisão quando houver $40 \%$ de folhas minadas com menos de $40 \%$ de minas predadas.

A utilidade de tais modelos está no fato de se correlacionar um conjunto de dados independentes (níveis de lesão ou doença) a um conjunto de variáveis dependentes (níveis de dano, diminuição de fotossíntese) (Bergamin Filho et al., 1995).

Gallo et al. (2002) referiram como nível de controle para L. coffeella, $40 \%$ das folhas com lagartas vivas na fase preparativa do cafeeiro (período seco do ano) e $20 \%$ de folhas com lagartas vivas na fase construtiva da cultura (período chuvoso).

\subsection{Métodos Fisiológicos para Estimativa de Nível de Controle}

Alternativamente, a abordagem mecanística para modelos de danos descreveria os vários processos fisiológicos do crescimento da planta e incorporaria os efeitos dos ataques de pragas nestes processos, usualmente como modelos de simulação. O uso de 
modelos mecanísticos é de extrema importância para um completo entendimento da resposta da produção à praga ou doença (Gaunt, 1987; Loomis et al., 1979; Loomis \& Adams, 1983; Pinnschmidt et al., 1994).

Boote et al. (1983) com base no efeito sobre processos relacionados ao fluxo de carbono na cultura, classificaram as pragas e patógenos em sete categorias: consumidores de tecidos, aceleradores da senescência foliar, redutores de estande, ladrões de luz, redutores da taxa fotossintética, consumidores de assimilados e redutores de turgescência, sendo que uma praga pode ser classificada em mais de uma categoria isolada ou simultaneamente. As primeiras quatro categorias representariam os principais efeitos das pragas e patógenos na interceptação da radiação pelas folhas, e as três últimas representariam os principais efeitos de uso da radiação absorvida (Johnson, 1987). A quantificação destes efeitos de pragas no crescimento da cultura tornaria possível acoplá-los em simuladores para prever reduções na produção.

Entre os processos fisiológicos da planta hospedeira alterados por pragas ou mesmo necroses foliares provocadas por insetos ou fatores abióticos como queimaduras de sol, destacam-se a taxa fotossintética, a taxa de respiração no escuro e a resistência do mesofilo e dos estômatos à difusão de $\mathrm{CO}_{2}$ (Bassanezi, 2000).

Das poucas generalizações que podem ser feitas com respeito à maneira pela qual as pragas e doenças afetam a fotossíntese, pode-se dizer que na maioria das interações planta-inseto, as taxas fotossintéticas líquidas e brutas diminuem œm o progresso da infestação, sendo que ocorre um aumento na fluorescência da clorofila, com conseqüente aumento da absorção de calor, maior respiração e maior transpiração.

Parece evidentemente claro que a redução da interceptação da radiação solar pela planta atacada, em razão da destruição, necrose, morte ou queda precoce dos tecidos fotossintetizantes da planta, é o principal resultado do ataque das pragas na redução da capacidade fotossintética da planta. Contudo, não se pode ignorar a possibilidade de que existam efeitos nos tecidos foliares adjacentes não infectados, implicando numa mudança da eficiência fotossintética neste tecido remanescente (Agrios, 1997; Goodman et al., 1986; Leite \& Pascholati, 1995; Lucas, 1998; Scholes, 1992). 
Monteith (1997) definiu a produção de uma cultura como o produto da radiação interceptada (RI) e a eficiência no uso dessa radiação (RUE). Os insetos, ácaros e fitopatógenos afetam de maneira diferente essas duas variáveis.

No caso da RUE, Bastiaans (1991) propôs a determinação da lesão virtual, caracterizado pelo parâmetro $\beta$, como uma das maneiras de dar mais significado biológico à avaliação da intensidade da doença.

Ribeiro et al. (2001) salientaram que algumas plantas ou grupo de plantas apresentam atividade enzimática cadenciada por ritmo circadiano; assim, devem ser padronizados os horários de leituras de trocas gasosas destas plantas, para sempre observar o período de maior atividade fotossintética, a fim de não se subestimar os valores de fotossíntese liqüida.

Loayza (1999) determinou o nível de controle de Selenaspidus articulatus (cochonilha de carapaça) em citros, utilizando a regressão não-linear proposta por Bastiaans(1991), determinando que 7\% de dano foliar seria o nível de controle desta praga.

No caso específico de ataque de alguns insetos e ácaros, Leite \& Pascholati (1995) observaram que ao estabelecerem relações alimentares com as plantas que atacam, esses insetos e ácaros, não causam somente danos físicos às mesmas (devido principalmente à introdução do seu aparato bucal nos tecidos) e retirada de substâncias da planta, mas podem também injetar substâncias estranhas nos tecidos da planta. Tais substâncias, originadas do próprio inseto, são componentes de suas secreções salivares, como aminoácidos e enzimas. Ao serem introduzidas nas plantas, estas substâncias podem provocar efeito deletério sobre as mesmas, constituindo-se, assim, em substâncias tóxicas, translocáveis ou não, à curta ou longa distância. Esse fenômeno resultante da interação toxicogênica da saliva do inseto nos tecidos da planta é chamado por alguns autores como toxemias ou fitotoxemias. Quando se elimina o agente estressor, geralmente a planta se recupera.

A avaliação dos danos causados pela cochonilha pardinha, Selenaspidus articulatus (Morgan, 1889), observados por Loayza (1999) foi obtida pela avaliação da atividade fotossintética de folhas sadias e doentes (diferentes níveis de lesão) através da 
taxa de assimilação de $\mathrm{CO}_{2}$ pela folha mantida sob determinada condição de iluminação, que fornece uma medida direta da taxa líquida de fotossíntese. Neves et al. (2001) de maneira análoga determinaram a taxa líquida de fotossíntese através da evolução de oxigênio em folhas de café 'Mundo Novo' sob ataque do bicho mineiro com diferentes áreas foliares lesionadas, determinando neste caso o intervalo entre 20 e 30\% de área foliar lesionada como sendo o nível de controle desta praga nesta cultivar.

Quando a folha é mantida no escuro, o que se mede é a liberação de $\mathrm{CO}_{2}$ pela respiração da folha (Long \& Hällgren, 1993). Quanto maior a assimilação de $\mathrm{CO}_{2}$ pela folha, maior sua atividade fotossintética e quanto maior a liberação de $\mathrm{CO}_{2}$ pela folha, maior sua atividade respiratória. Qualquer mudança na atividade fotossintética ou respiratória da folha será refletida na concentração final de $\mathrm{CO}_{2}$ medida.

Via de regra, a maioria dos estudos de troca de $\mathrm{CO}_{2}$ tem envolvido métodos em que as folhas ficam confinadas em câmaras transparentes e a taxa de assimilação de $\mathrm{CO}_{2}$ é determinada pela medição na variação da concentração de $\mathrm{CO}_{2}$ no ar que atravessa a câmara. Nos sistemas usados, o ar passa dentro de um analisador de gás a infravermelho (IRGA) que continuamente registra a concentração de $\mathrm{CO}_{2}$ no sistema, verificando a diferença entre o ar que atravessa a câmara com a folha e o ar que entra na câmara. A taxa de assimilação ou liberação de $\mathrm{CO}_{2}$ é expressa como a quantidade de $\mathrm{CO}_{2}$ assimilado ou liberado por unidade de área foliar e tempo $\left(\mu \mathrm{mol} \mathrm{CO} \mathrm{Cm}^{-2} \mathrm{~s}^{-1}\right)$.

As variáveis que comumente são obtidas por sistemas de trocas gasosas são a taxa fotossintética (iluminada), taxa respiratória (no escuro), taxa de transpiração, concentração intercelular de $\mathrm{CO}_{2}$ e condutância ou resistência estomática. Os cálculos destas variáveis são baseados nos modelos desenvolvidos por Farquar et al., (1980) e Farquar \& von Caemmerer, (1982), e ainda são a base para a interpretação das avaliações de trocas gasosas.

Delieu \& Walker (1981) desenvolveram um método polarográfico de medição de evolução de $\mathrm{O}_{2}$ fotossintético (Eletrodo de Clark) em discos foliares, com $10 \mathrm{~cm}^{2}$ de área, mantidos em câmara fechada, sob luz e $\mathrm{CO}_{2}$ saturantes em condições ótimas de temperatura, avaliando desta forma a quantidade de $\mathrm{O}_{2}$ liberado por unidade de área foliar por tempo $\left(\mu \mathrm{mol} \mathrm{O} \mathrm{O}^{-2} \mathrm{~s}^{-1}\right)$. 
O método de análise de gás por infravermelho (IRGA) é mais usado devido à sua praticidade, por ser portátil, não precisar destruir a parte da planta alvo de estudos e ainda permitir o acoplamento de outros sensores que possibilitam leituras de condutância estomática, concentração interna de $\mathrm{CO}_{2}$, respiração e transpiração celular e potencial hídrico ou turgescência foliar. 


\section{MATERIAL E MÉTODOS}

Os ensaios foram realizados no Laboratório de Biologia de Insetos, do Departamento de Entomologia, Fitopatologia e Zoologia Agrícola e no Laboratório de Fisiologia de Plantas em Estresse, do Departamento de Ciências Biológicas, na Escola Superior de Agricultura Luiz de Queiroz, da Universidade de São Paulo (ESALQ/USP).

\subsection{Obtenção de Mudas}

As mudas utilizadas durante todo o desenvolvimento da pesquisa, foram obtidas através de produtores e viveiristas.

\subsubsection{Obtenção de mudas de limão cravo (Citrus limonia L.)}

Foram utilizadas mudas de limão cravo, mantidas em tubetes, obtidas junto à Fischer Agropecuária SA, em Matão, SP, num total de 1500 mudas.

\subsubsection{Obtenção de mudas de café 'Obatã'}

Foram utilizadas mudas de café 'Obatã' mantidas em tubetes, cedidas pela Garcafé - Cooperativa do Cafeicultores do Município de Garça e Região- num total de 1000 mudas. 


\subsection{Criação de Insetos}

\subsubsection{Criação de Orthezia praelonga Douglas, 1891}

Foram realizadas coletas regulares de cochonilhas da espécie $O$. praelonga, no campo experimental do Departamento de Produção Vegetal da ESALQ/USP, mantendose colônias estoques no Laboratório de Biologia de Insetos, do Departamento de Entomologia, Fitopatologia e Zoologia Agrícola da ESALQ/USP durante todo o trabalho experimental.

Folhas de citros infestadas com formas jovens e adultas da cochonilha foram colocadas sobre plantas de Croton sp. para que fêmeas e machos desta praga pudessem se alimentar e multiplicar-se nesta planta. As plantas de cróton foram transferidas para casa-de-vegetação com circulação forçada de ar através de ventiladores, sem controle de umidade, com temperatura variável entre $27^{\circ} \mathrm{C} \pm 3^{\circ} \mathrm{C}$ e fotoperíodo natural.

As infestações de folhas de limão cravo em tubetes de material plástico $(3,5 \mathrm{~cm}$ de diâmetro $\mathrm{X}$ 12,5 $\mathrm{cm}$ de comprimento) foram feitas de forma semelhante, pela sobreposição de folhas de cróton contendo insetos sobre aquelas ou pelo contato direto das mudas em tubetes com as plantas hospedeiras por períodos variáveis entre 24 e 48 horas. As plantas de limão cravo infestadas por $O$. praelonga em diferentes níveis de área foliar lesionada foram usadas nos ensaios de medição de fotossíntese, condutância estomática, transpiração foliar, concentração interna de $\mathrm{CO}_{2}$ e temperatura foliar.

\subsubsection{Criação de Leucoptera coffeella (Guérin-Mèneville, 1842)}

A partir de coletas regulares, feitas no campo experimental do Departamento de Produção Vegetal da ESALQ/USP, Setor de Agricultura, foi estabelecida, em laboratório, uma criação estoque de L. coffeella.

Folhas infestadas pelo bicho-mineiro foram trazidas do campo e mantidas em caixas plásticas fechadas, do tipo "baleiro", revestidas por sacos de papel que não permitiam a passagem da luz e contendo tubos de ensaios presos à tampa (para a coleta dos adultos emergidos e que voam em busca da luminosidade); estas caixas foram 
mantidas em laboratório com temperatura de $26^{\circ} \mathrm{C} \pm 1,5^{\circ} \mathrm{C}$; UR de $60 \pm 10 \%$ e fotofase de 14 horas.

Através de monitoramento diário, adultos emergidos destas folhas foram colocados em gaiola de acrílico de formato retangular $(90 \mathrm{~cm}$ de comprimento X $54 \mathrm{~cm}$ de altura maior e $36 \mathrm{~cm}$ de altura menor X $44 \mathrm{~cm}$ de largura), com fundo de "voile" e tampo superior de vidro; tais adultos foram alimentados com mel puro, colocado em forma de filetes nas paredes e tampo superior da gaiola.

Dentro desta gaiola, foi colocado número variável de mudas de cafeeiro cultivar Obatã, plantadas em tubetes de material plástico (4,6 cm de diâmetro X 14,0 cm de comprimento), e que aí permaneceram por período maior do que 24 horas e menor do que 72 horas (quatro dias), para a oviposição obtida com número variável de mariposas aí colocadas.

As plantas infestadas foram levadas à casa-de-vegetação com fotoperíodo natural, temperatura de $26^{\circ} \mathrm{C}$ a $28^{\circ} \mathrm{C}$, UR\% de 70 a $75 \%$, e circulação forçada de ar, com pad-fan. Novas mudas sadias eram colocadas no lugar das plantas retiradas contendo ovos, nas gaiolas mencionadas.

Após esta transferência, parte das mudas na casa-de-vegetação, eram inspecionadas a partir do $9^{9}$ dia, para a observação da transformação das lagartas em pupas, as quais eram coletadas. As folhas com pupas eram colocadas em caixas de plástico ( $26 \mathrm{~cm}$ de comprimento X $8 \mathrm{~cm}$ de altura X $14 \mathrm{~cm}$ de largura), com apenas um orifício na tampa, fechado por "voile"; e, a seguir, mantidas em câmaras climatizadas, reguladas nas temperaturas de $20,22,25,28$ e $30^{\circ} \mathrm{C}$, para obtenção de insetos adultos de acordo com a necessidade de renovação da colônia. $\mathrm{O}$ sistema de criação permitiu o suprimento contínuo de insetos durante toda a pesquisa. As folhas de café com lesões de L. coffeella foram utilizadas para medição de fotossíntese, condutância estomática, transpiração foliar, concentração interna de $\mathrm{CO}_{2}$ e temperatura foliar.

Os níveis de lesão foliar foram obtidos através do número variável de lagartas por folha (obtidas em função da manutenção ou retirada de ovos nas folhas antes da eclosão das lagartas) e pelo tempo de progressão da infestação (desenvolvimento larval 
do inseto), onde lagartas mais velhas por consumirem maior quantidade de tecido proporcionaram maior área foliar lesionada.

\subsection{Medição de fotossíntese, condutância estomática, transpiração foliar, concentração interna de $\mathrm{CO}_{2}$ e temperatura foliar em folhas de limão cravo atacadas por $O$. praelonga, e em folhas de cafeeiro 'Obatã' atacadas por $L$. coffeella}

Folhas de limão cravo com diferentes níveis de lesões, que após a análise estatística puderam ser agrupadas em quatro intervalos distintos, 0 a 6 (de 0 a 35 cochonilhas/folha); 7 a 13 (de 40 a 70 cochonilhas/folha); 14 a 40 (de 80 a 220 cochonilhas/folha) e $>40 \%$ (>220 cochonilhas/folha)de área foliar lesionada, causadas por $O$. praelonga, foram utilizadas para a medição de fotossíntese máxima por meio da avaliação de trocas gasosas, com um medidor portátil de fotossíntese do tipo analisador infra-vermelho de gases (Infra-red Gas Analyser) (IRGA LI-6400, LI-COR ${ }^{\circledR}$, Nebrasca/USA) (Figura 3A) sendo a saturação lumínica de $0,6 \mathrm{mmol}$ de fótons $\mathrm{m}^{-2} \mathrm{~s}^{-1}$, dentro de uma câmara de $6 \mathrm{~cm}^{2}$ de área com iluminação artificial própria (Figura 3B), onde foi introduzida a folha a ser analisada. No interior da câmara foi posicionado o sensor de $\mathrm{CO}_{2}$ e umidade, um termopar de referência e outro tocando a face inferior da folha (Long \& Hällgren, 1993). A concentração de $\mathrm{CO}_{2}\left( \pm 38 \mathrm{mmol} \mathrm{mol}^{1}\right)$ foi gerada por injeção direta de gás carbônico, via cilindro pressurizado e mangueira, com conectores específicos a esta finalidade, numa pressão constante de $14 \mathrm{kgf.cm}^{-2}$, com o coeficiente de variação do ar interno da câmara sempre menor que 1\%. As variáveis condutância estomática, transpiração foliar, concentração interna de $\mathrm{CO}_{2}$ e temperatura foliar foram medidas concomitantemente à fotossíntese por sensores específicos já instalados no interior da câmara. A área lesionada foi medida através de um Analisador Digital de Imagens Delta T Devices (Figura 3C), que consiste em uma mesa de aquisição de imagens acoplada a um microcomputador; e com um software próprio (WinDIAS), desenvolvido para esta finalidade; foi determinada a área lesionada por comparação 
direta entre o tecido necrosado e o tecido sadio em relação à área total $\left(6 \mathrm{~cm}^{2}\right)$ por contraste de coloração de imagens (Webb \& Jenkins, 2000).

A temperatura no interior da câmara foi de $28^{\circ} \mathrm{C}$ (Ribeiro, 2002), controlada automaticamente pelo equipamento.

Foram utilizadas folhas totalmente expandidas do terço médio das plantas com diferentes porcentagens de área foliar lesionada obtidas em laboratório pelo variação do número de insetos fixados na superfície abaxial das folhas, num mínimo de 200 leituras neste intervalo. Os diferentes tratamentos foram comparados ao tratamento testemunha que constou da planta sadia, mantida nas mesmas condições de temperatura, luz e umidade. Visando garantir a total abertura estomática foi injetado na câmara um fluxo de ar enriquecido com vapor d'água a uma pressão constante de 1,5 kPa (Bernacchi et al, 2001), através de um gerador de ponto de orvalho (LI-610, LI-COR, Nebrasca/USA), em ambos os casos.

Visando eliminar a interferência da presença da cochonilha no interior da câmara, que poderia levar a uma análise subestimada da fotossíntese, em um ensaio preliminar foi avaliada a assimilação de $\mathrm{CO}_{2}$ por limão cravo com e sem a presença da praga (Loayza, 1999).

De maneira análoga, folhas de cafeeiro 'Obatã' com diferentes níveis de lesões, de 0 a $100 \%$ de área foliar lesionada, causadas por L. coffeella, obtidas em laboratório foram utilizadas para a medição de fotossíntese, condutância estomática, transpiração foliar, concentração interna de $\mathrm{CO}_{2}$ e temperatura foliar. Utilizaram-se folhas do segundo e terceiro internódios, a partir do ápice, jovens, porém maduras e totalmente expandidas por serem as fotossinteticamente mais ativas, conforme menciona a literatura e preferidas pelo bicho mineiro (Parra, 1981).

A fotossíntese líquida máxima, neste caso, expressa pela assimilação de gás carbônico $\left(\mathrm{A}_{\max }\right)$, foi medida sob luz e $\mathrm{CO}_{2}$ saturantes, a $35^{\circ} \mathrm{C}$, controlada automaticamente pelo equipamento, com a saturação lumínica de 1,2 mmol de fótons $\mathrm{m}^{-2} \mathrm{~s}^{-1}$. 
Os níveis de área foliar lesionada foram obtidos selecionando-se folhas de diferentes quantidades de tecido consumido pela lagarta e pela variação do número de lagartas por folhas.

\subsection{Delineamento estatístico}

Os resultados de fotossíntese obtidos em cada ponto de área foliar lesionada, nos dois ensaios (O. praelonga infestando citros e L. coffeella infestando café) foram submetidos à análise de variância e as médias comparadas pelo teste de Tukey, ao nível de 5\% de probabilidade, sendo que os valores que não diferiram estatisticamente foram agrupados em intervalos de área foliar lesionada, constituindo-se quatro intervalos distintos para o ataque de $O$. praelonga em folhas de limão cravo: 0 a 6\%, 7 a 13\%, 14 a $40 \%$ e $>40 \%$ de área foliar lesionada (Figura 4); para o caso das lesões de L. coffeella em folhas de cafeeiro foram definidos três intervalos distintos: 0 a 25\%, 26 a $36 \%$ e $>37 \%$ de área foliar lesionada (Figura 5), sendo estes intervalos tomados como referência para as demais variáveis fisiológicas vegetais. Ainda em relação ao ataque de O. praelonga em folhas de limão cravo, procedeurse à contagem manual do número de insetos, retirados com auxílio de estilete, para os limiares inferior e superior do intervalos de área foliar lesionada descritos, quais sejam: 0 a 6\%: de zero a 35 insetos por folha; de 7 a 13\%: de 40 a 70 insetos por folha; de 14 a 40\%: 80 a 220 insetos por folha, e >40\%: mais de 220 insetos por folha, aproximadamente.
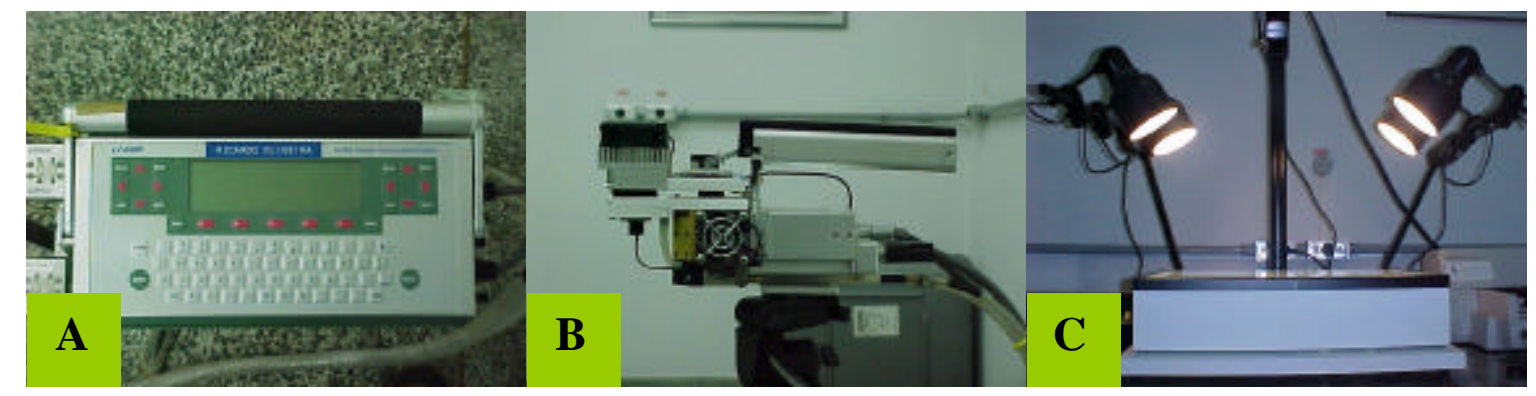

Figura 3 - Equipamentos utilizados na medição de fotossíntese: console do IRGA (A), câmara de $\mathrm{CO}_{2}$ (B) e mesa digitalizadora de imagens Delta T Devices (C) 

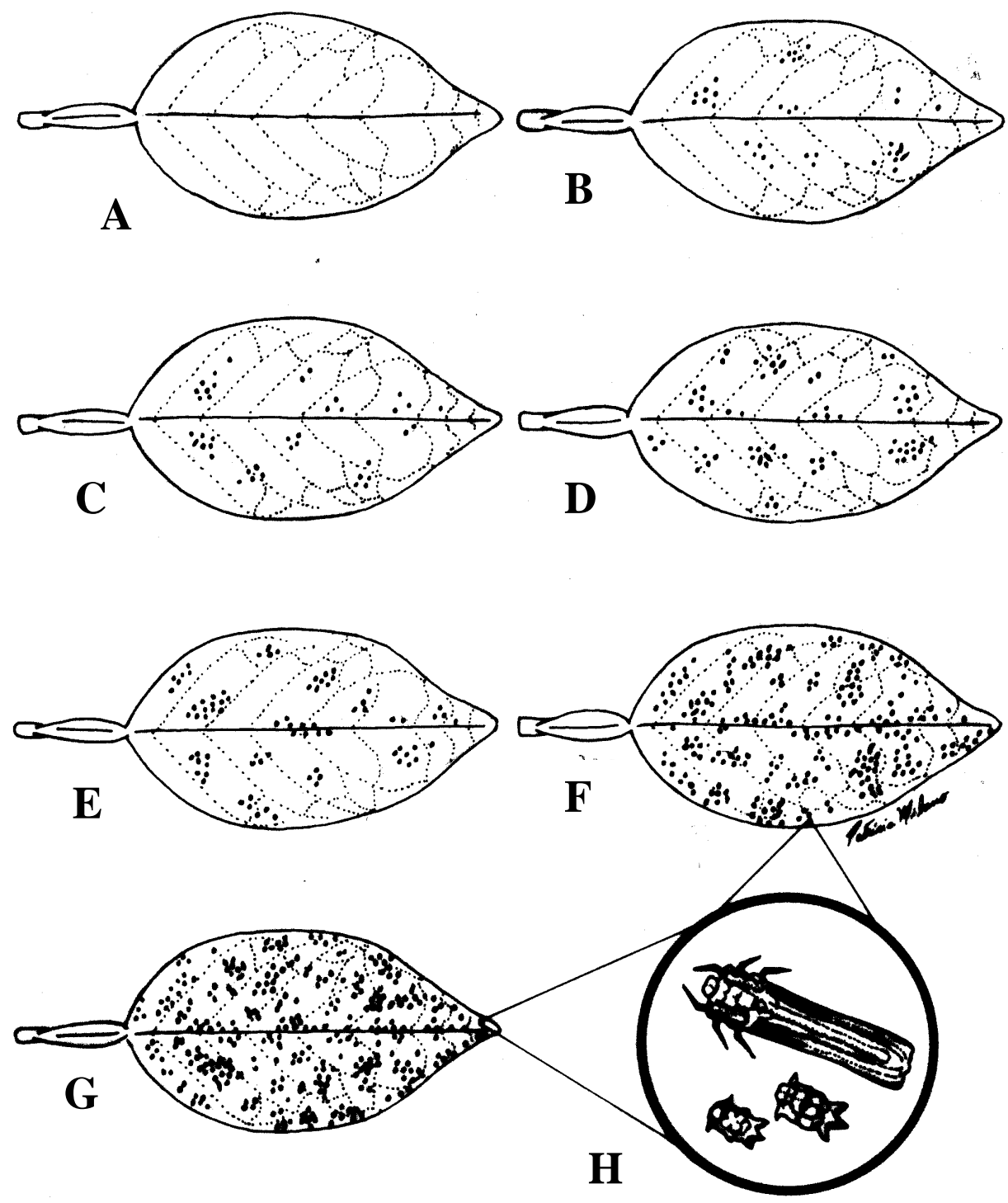

Figura 4 - Intervalos de área foliar lesionada por O. praelonga em limão cravo considerados para avaliação de variáveis fisiológicas vegetais: $0 \%=0$ cocho nilha $(\mathrm{A}) ; 6 \% \pm 35$ cochonilhas $(\mathrm{B}) ; 7 \%$ \pm 40 cochonilhas $(\mathrm{C}) ; 13 \% \pm 70$ cochonilhas (D); $14 \% \pm 80$ cochonilhas $(\mathrm{E}) ; 40 \% \pm 220$ cochonilhas $(\mathrm{F}) ;>40 \% \Rightarrow>220$ cochonilhas $(\mathrm{G})$; Detalhe fềmea e ninfas $(\mathrm{H})$ 


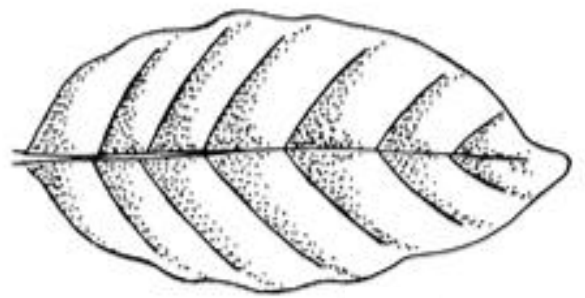

A

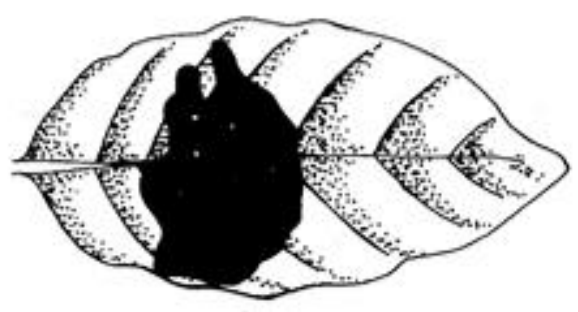

C

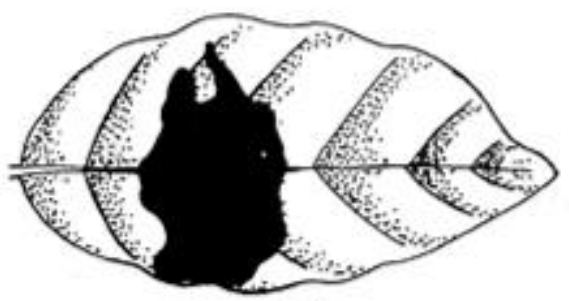

B

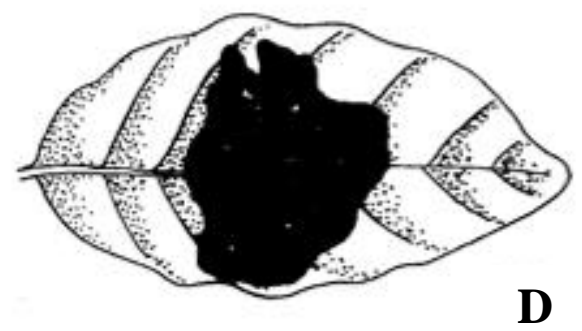

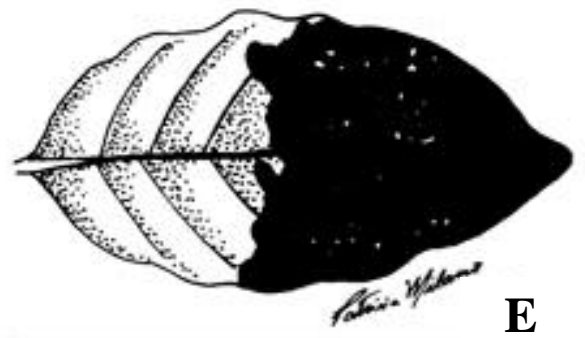

Figura 5 - Intervalos de área foliar lesionada por L. coffeella em cafeeiro 'Obatã' considerados para avaliação de variáveis fisiológicas vegetais: $0 \%=$ folha sadia (A); $25 \%$ de área lesionada (B); $26 \%$ de área lesionada (C); 36\% de área lesionada (D); >36\% de área lesionada $( \pm 50 \%)(\mathrm{E})$ 


\section{RESULTADOS E DISCUSSÃO}

\subsection{Medição de fotossíntese, condutância estomática, transpiração foliar, concentração interna de $\mathrm{CO}_{2}$ e temperatura foliar em folhas de limão cravo atacadas por Orthezia praelonga Douglas, 1891, e em folhas de cafeeiro 'Obatã' atacadas por Leucoptera coffeella (Guérin-Mèneville, 1842)}

\subsubsection{Acertos Metodológicos}

No ensaio preliminar, visando avaliar se a presença da cochonilha no interior da câmara poderia levar a um valor subestimado de fotossíntese, chegou-se àseguinte conclusão: os resultados de leituras de fotossíntese em folhas de limão cravo lesionadas com e sem a presença de cochonilhas não mostraram diferenças significativas, sendo que com a presença das cochonilhas os valores de assimilação de gás carbônico em folhas com sintomas em níveis diferentes foram, na maioria dos casos, no máximo 0,5\% menores em relação às folhas sem as cochonilhas (retiradas cuidadosamente com um estilete, visando não provocar novas injúrias mecânicas), levando à suposição de que a respiração destes insetos não é suficientemente alta e o $\mathrm{CO}_{2}$ por elas produzido não afeta de maneira significativa a leitura da taxa liquida (ou relativa) de fotossíntese a ponto de causar erros, subestimando esta variável (Figura 6).

Devido ao diminuto aparato bucal, a inserção do rostro da cochonilha ortézia na folha não levou à formação de halos amarelados ou regiões necróticas (Figura 5), que via de regra diminuem a área de absorção de radiação solar, com conseqüente redução da fotossíntese, conforme observado por Loayza (1999), no patossistema de Selenaspidus articulatus (Morgan, 1889) em folhas de limão cravo ou na relação de Aspidiotus destructor Signoret em coqueiro e outras palmáceas, com acentuado amarelecimentodefolhas, característica do ataque de diaspidídeos (Beardsley \& 
Gonzáles 1975). Em frutos de maçã e pêssego, 10 a 12 horas após a fixação, Gonzáles (1981) constatou a presença de uma mancha avermelhada em torno de Quadraspidiotus perniciosus (Comstock). Também Carter (1962) citado por Gonzáles (1981), estudou o mecanismo de alimentação de diaspidídeos e determinou que, possivelmente, o efeito tóxico produzido pelo inseto se deve à ação de dois ou mais componentes presentes na saliva, que podem agir de forma conjunta (sinérgica) ou isoladamente.

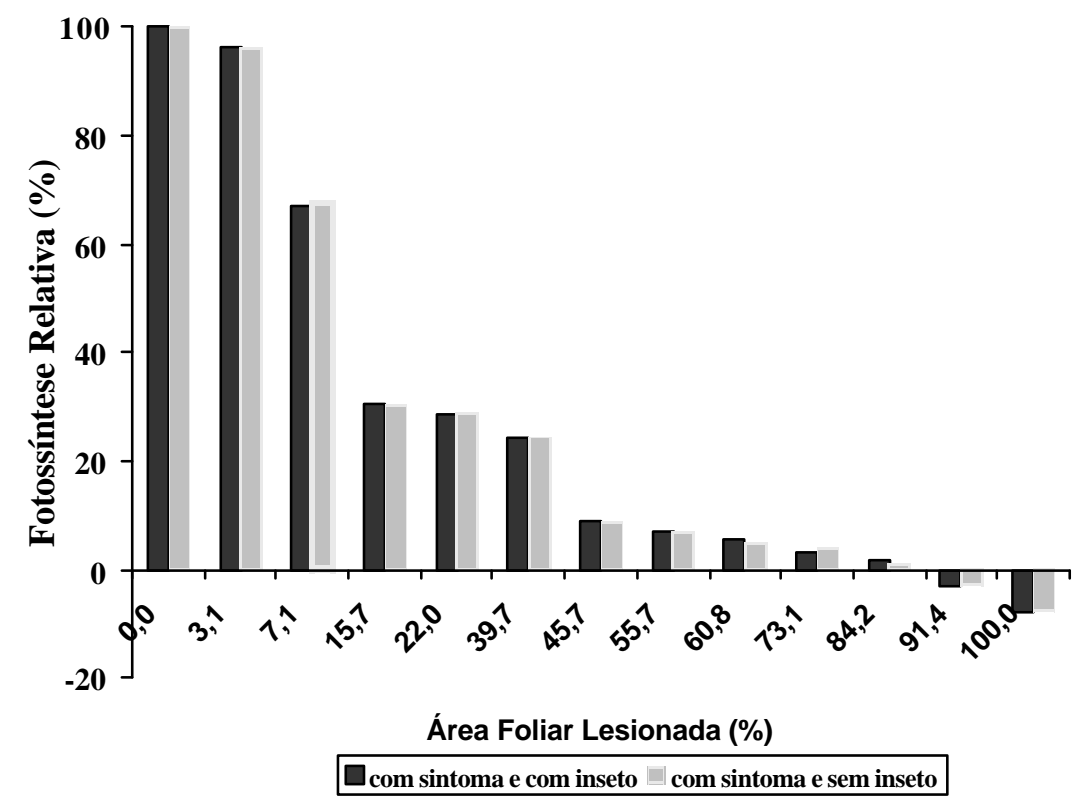

Figura 6 - Fotossíntese relativa de folhas de limão cravo sob ataque de $O$. praelonga, com e sem a presença da cochonilha nas folhas 


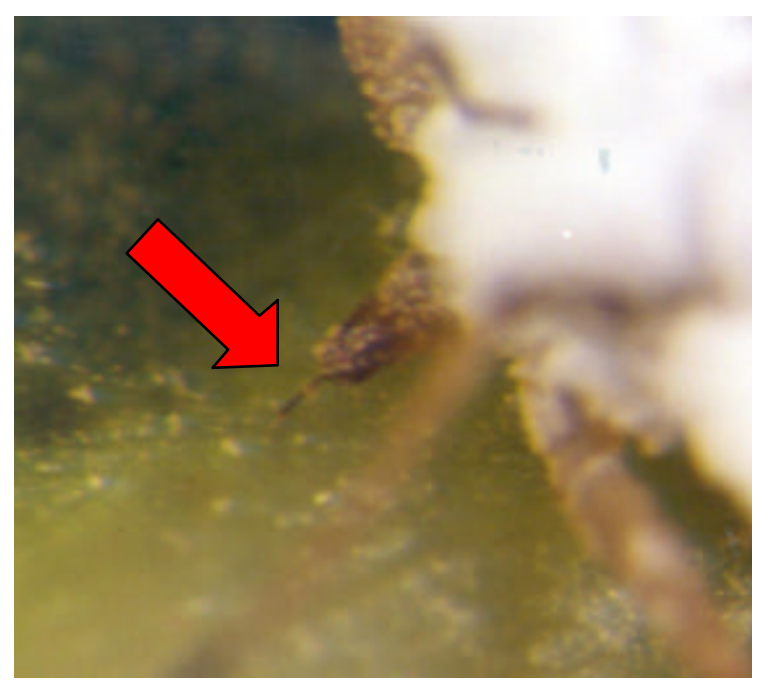

Figura 7 - Fêmea de $O$. praelonga em folha de limão cravo, com destaque para o rostro inserido na lâmina foliar (aumento: 80X)

Em relação às folhas de cafeeiro 'Obatã' atacadas por L. coffeella, devido ao hábito alimentar da praga, que consome unicamente o parênquima paliçádico das folhas (Cárdenas Murillo \& Orozco Castaño, 1983; Ramiro et al. 2003), ocorre a destruição de pigmentos fotossintéticos (consumidos pelo inseto), além da necrose do tecido; em altas infestações, por conter, em uma lesão mais de uma lagarta e muitas vezes de idades diferentes, a saída de uma lagarta permite novas aberturas, que possibilitam a entrada de outros agentes patogênicos que podem atuar em conjunto com a praga na redução de captação de radiação solar, sendo comum a observação de um pequeno halo amarelado em torno da lesão (Figura 8). 

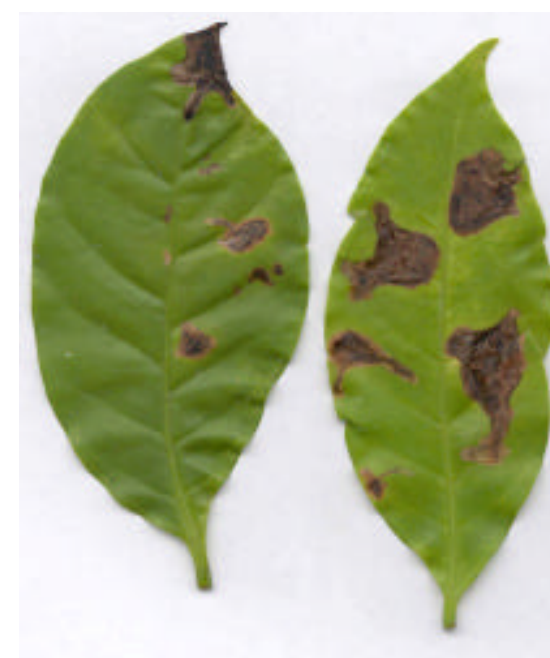

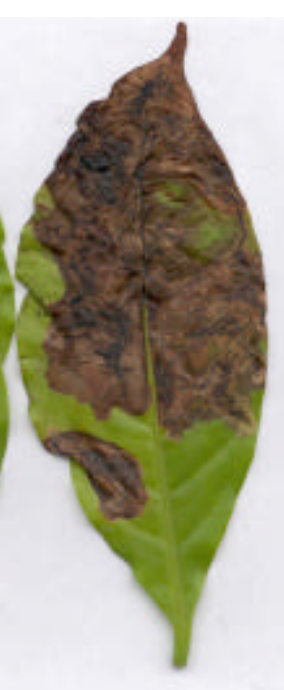

Figura 8 - Lesões necróticas de diferentes proporções em folhas de cafeeiro causadas por L. coffeella.

\subsubsection{Avaliações da fotossíntese}

Uma regressão não linear, foi utilizada para a análise dos dados, por ser, segundo Baastians (1991), a melhor opção para este tipo de avaliação, pois relaciona a intensidade de dano provocado por uma praga ou patógeno em plantas, permitindo correlacionar a área foliar lesionada e a fotossíntese líquida ou relativa. Os efeitos de $O$. praelonga na fotossíntese de folhas de limão cravo e de L. coffeella em folhas de cafeeiro 'Obatã' demonstraram uma correlação negativa entre a infestação (número de cochonilhas por folha ou tecido foliar consumido) e a fotossíntese relativa, isto é, quanto maior a lesão provocada pelo ataque das pragas, menor a fotossíntese relativa (Figuras 9A e 10A).Os valores absolutos de fotossíntese de limão cravo (fotossíntese líquida) para a planta sadia ficaram em torno de $4 \mu \mathrm{mol} \mathrm{CO}_{2} \cdot \mathrm{m}^{-2} \cdot \mathrm{s}^{-1}$, considerada baixa em relação a outras espécies arbóreas, porém dentro do padrão admitido nas cultivares de citros (Kriedmann, 1971); para as plantas de cafeeiro, a fotossíntese liquida encontrada foi de 4,28 $\mu \mathrm{mol} \mathrm{CO}_{2} \cdot \mathrm{m}^{-2} \cdot \mathrm{s}^{-1}$, apontado como o padrão para este e outras cultivares (Icatu e Acaiá) por Souza (2001). 
A análise das médias de fotossíntese (item 3.4) permitiu, nos dois ensaios, agrupar em intervalos de área foliar lesionada para os pontos que não diferiram estatisticamente; estabelecendo-se quatro intervalos distintos: de 0 a $6 \%$ (0-35 cochonilhas/folha); 7 a $13 \%$ (40-70 cochonilhas/folha); 14 a $40 \%$ (80-220 cochonilhas/folha) e >40\% (>220 cochonilhas/folha) de área foliar lesionada (também tomados como referência manálise das demais variáveis) para O. praelonga (Figura 9B). Os valores de assimilação de gás carbônico, para folhas de limão cravo com infestações variando de 0 a $6 \%$, não diferiram entre si, com valores médios de fotossíntese relativa de $96 \%$; porém ao aumentar em 1\% a infestação, (7-13\%) notou-se uma abrupta diminuição da fotossíntese relativa, que atingiu valores médios em torno de $65 \%$, e para áreas lesionadas com severidade entre 14 e $40 \%$, a fotossíntese relativa foi reduzida ao patamar de $28 \%$, chegando a valores próximos de $4 \%$ com mais de $40 \%$ de área foliar lesionada. A partir destes dados, tomourse o ponto de inflexão negativo da curva, onde um pequeno aumento da área foliar lesionada resultou em uma grande perda da assimilação de gás carbônico, como sendo o nível de dano, ou seja, na prática o valor ficou na faixa de 7 a 13\% da área foliar lesionada, indicando que o nível de controle desta praga está aquém destes valores. Como maneira de facilitar a interpretação dos resultados, a contagem manual das cochonilhas nos limiares inferior e superior desta faixa, permitiu estabelecer que o nível de infestação de 7\% corresponde, a mais ou menos, 40 cochonilhas novas por folhas, e o nível de 13\% corresponde a mais ou menos 70 cochonilhas novas por folhas. Portanto, o nível de controle encontra-se abaixo de infestações de 40 cochonilhas por folha.

De maneira análoga, na interação de L. coffeella, em folhas de cafeeiro 'Obatã', a análise das médias de assimilação de $\mathrm{CO}_{2}$ (Item 3.4), permitiu o agrupamento das médias que não diferiram em três intervalos: de 0 a $25 \%$; de $26-36 \%$ e de $37-100 \%$ de área foliar lesionada (Figura 10B).

A fotossíntese relativa, neste caso, apresentou valores médios de $87 \%$ no intervalo de 0 a $25 \%$ de área foliar lesionada; de $55 \%$ no intervalo de $26-36 \%$ e de $18 \%$ no intervalo de 37 a 100\% de área foliar lesionada, indicando que o nível de dano em 
relação a esta variável fisiológica vegetal encontra-se na faixa de 26 a 36\% de área foliar lesionada, indicando que o nível de controle desta praga está aquém destes valores.
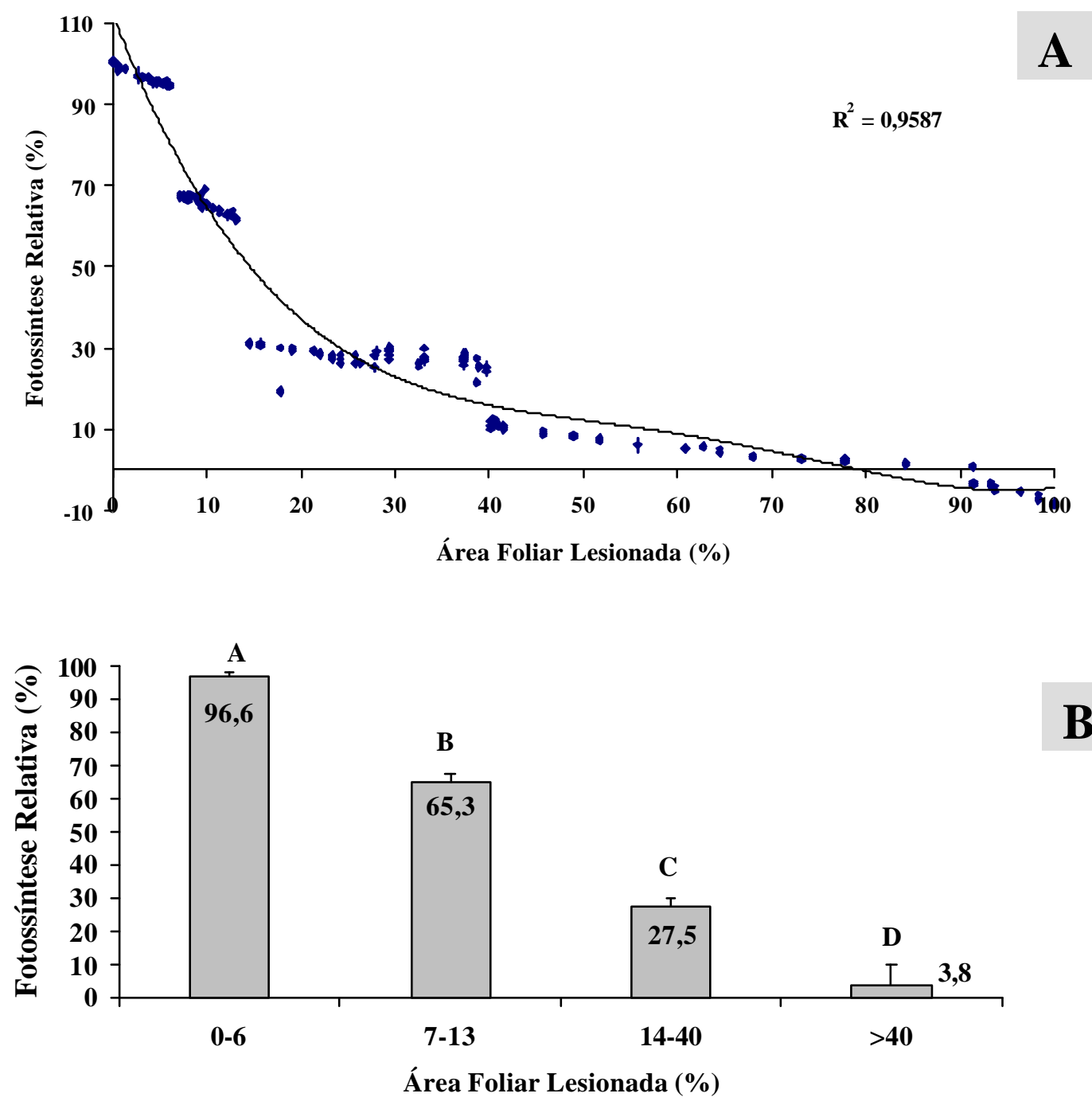

Figura 9 - Efeito da área foliar lesionada (0 a 100\%) por O. praelonga sobre a fotossíntese relativa (A) e efeito da intensidade de infestação de $O$. praelonga em quatro intervalos na fotossíntese relativa $(\%) \mathrm{em}$ folhas de limão cravo (B). Tratamentos seguidos da mesma letra não diferem entre si, pelo teste de Tukey, ao nível de 5\% de probabilidade 

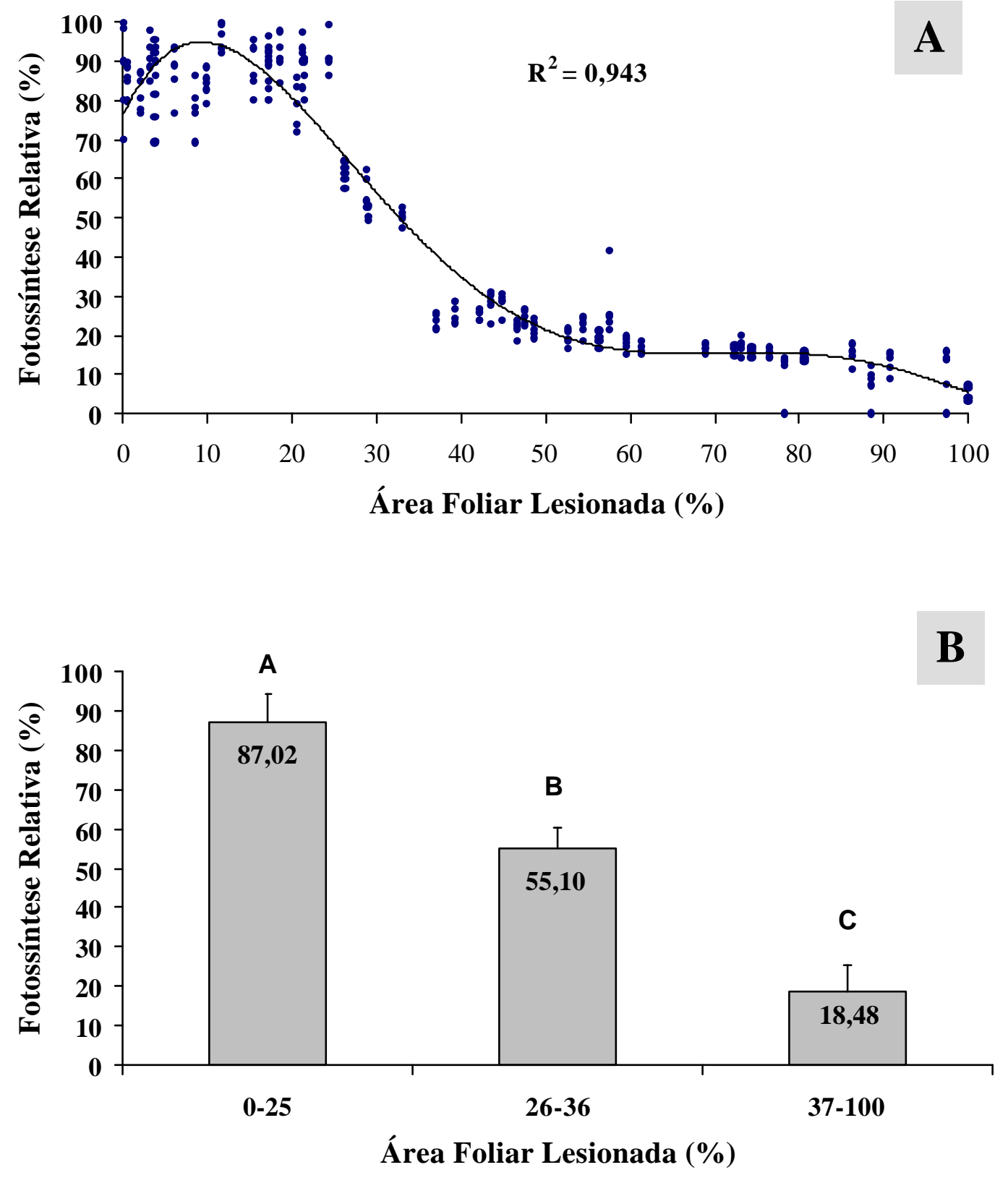

Figura 10 - Efeito da área foliar lesionada (0 a 100\%) por L. coffeella sobre a fotossíntese relativa (A) e efeito da intensidade de infestação de L. coffeella em três intervalos na fotossíntese relativa (\%) em folhas de cafeeiro 'Obatã' (B). Tratamentos seguidos da mesma letra não diferem entre si, pelo teste de Tukey, ao nível de 5\% de probabilidade 
A diminuição da fotossíntese pode ocorrer: devido a interferências no conjunto fotossintético em função da destruição do tecido fotossintetizante, que pode ser decorrente de lesões, bem como por alterações produzidas no metabolismo da área verde remanescente de folhas doentes, incluindo a taxa de absorção de $\mathrm{CO}_{2}$, no teor de pigmentos e nas atividades de enzimas do ciclo de Calvin (Stangarlin \& Pascholati, 2000). Segundo Baastians (1991) a redução na btossíntese de uma folha doente em função de alterações produzidas no metabolismo da área verde remanescente, deve-se a diversos mecanismos que poderiam modificar a eficiência fotossintética de plantas em condições de estresse, incluindo: mudanças na taxa de absorção de gás carbônico devido a alterações no comportamento de abertura/fechamento dos estômatos (Gordon \& Duniway, 1982); diminuição na interceptação da radiação solar como conseqüência de desfolha ou mudanças no formato e/ou orientação das folhas (Madeira \& Clark, 1995); incremento da atividade da enzima clorofilase, responsável pela hidrólise de clorofila (Bailiss, 1970); destruição acelerada e contínua de cloroplastos (Abo-Foul et al., 1996); retenção dos níveis de clorofila com a formação de regiões verdes (Sziráki et al., 1984); alteração na atividade ou nos níveis de mRNA que codificam enzimas do ciclo de Calvin, como a ribulose - 1,5 bifosfato carboxilase-oxigenase (rubisco), responsável pela fixação de $\mathrm{CO}_{2}$ na planta (Scholes \& Rolfe, 1995) e acúmulo de carboidratos causando retroinibição e regulação da expressão gênica (Scholes et al., 1994).

A metodologia utilizada não permite testar todas as hipóteses listadas, porém algumas são passíveis de exclusão, como no caso de ataque de $O$. praelonga às folhas de limão cravo; neste caso, pode-se eliminar a hipótese de que a fotossíntese tenha diminuído em função do acúmulo de carboidratos, o que levaria a uma retroinibição (Scholes et al., 1994), pois devido à característica alimentar da cochonilha de sugar continuamente a seiva das plantas, não há possibilidade de armazenamento de carboidratos na folha; inclusive, observa-se constantemente a presença de "honeydew", liberado em grandes quantidades pelo inseto. Também não foram notadas mudanças no formato de folhas (Madeira \& Clark, 1995), mas sim no brilho desde que elas passaram a ter uma tonalidade opaca em comparação às folhas sadias; porém, em grande número, as colônias de cochonilhas encobrem porções significativas da área foliar, o que sem 
dúvida levaria a uma alteração na absorção de luz radiante e conseqüente diminuição no aproveitamento do fluxo de fótons fotossinteticamente ativos, com possível estresse e danos no fotossistema II (PSII); a mesma observação se aplica ao bicho-mineiro em folhas de café; contudo, conforme relatado por diversos autores, como Goodman et al., (1986); Scholes, (1992); Leite \& Pascholati; (1995); Agrios, (1997) e Lucas, (1998); não se pode ignorar a possibilidade de que compostos químicos, presentes na saliva do inseto, ou então provenientes de outros agentes presentes na mina, exerçam efeitos em tecidos adjacentes visualmente sadios (não lesionados), implicando numa mudança da eficiência fotossintética deste tecido. A adulteração fisiológica do PS II, por meio de destruição ou inativação do pigmento responsável pela captação de luz, impossibilitaria a fase bioquímica da fotossíntese (PS I), pois sem a amplificação indutiva da luz recebida, não ocorrerá a liberação de elétrons para a realização da fase bioquímica da fotossíntese (Taiz \& Zeiger, 2004).

A ação deletéria da praga (fitotoxemia) pode estar afetando o transporte de elétrons nos cloroplastos dos tecidos remanescentes em função da redução da absorção de fotóns recebidos (Pons \& Bergkotte, 1996), de maneira direta por substâncias tóxicas por ela injetada ou por componentes tóxicos provenientes de outros organismos presentes na galeria. A diminuição na atividade do PS II, entretanto, não resulta exclusivamente da redução do conteúdo de clorofila, mas também da redução na concentração de plastoquinona, redução da reação de Hill e da fotofosforilação e acúmulo de carboidratos no tecido foliar (Goodman et al., 1986)..

De acordo com dados da literatura, é comum as plantas possuírem em suas folhas um número muito maior de cloroplastos e pigmentos fotossintéticos (clorofila a, clorofila b, caroteno e xantofila) além do necessário, para que, se preciso, a mudança na orientação de folhas ou exposição destes cloroplastos compensem deficiências luminosas ao longo do dia, o que corrobora a hipótese de Monteith \& Elston (1983) e Squire (1990) de que a produção depende da parte remanescente sadia da folha, e não da parte atacada. Assim, a planta provocaria o deslocamento (ciclose) de cloroplastos e pigmentos para a área verde remanescente como forma de compensar as áreas encobertas (destruídas) pelas pragas; isto resultaria em um aumento significativo da 
atividade da fase fotoquímica (PSII) no tecido sadio, produzindo em grande quantidade ATP, NADPH e liberação de oxidantes fortes, o que poderia levar a um dano fisiológico neste tecido, caracterizando assim, um dano indireto provocado pela praga. Neste caso, é comum observar-se um aumento da fluorescência da clorofila, levando a uma maior temperatura foliar com alterações de fluidez de membranas. Os processos fotoquímicos, como a captação de luz e transporte de elétrons, são relativamente imunes aos efeitos diretos da temperatura; porém, esses processos sofrem influência direta das alterações nos processos bioquímicos e das mudanças na fluidez das membranas dos tilacóides induzidas pelo calor (Nilsen \& Orcutt, 1996), e segundo Schreiber \& Berry (1977), um dos primeiros componentes do conjunto fossintético a ser danificado pelo aumento da temperatura da folha são as membranas dos tilacóides, onde está inserida uma grande variedade de proteínas essenciais à fotossíntese (Taiz \& Zeiger, 2004).

Em temperaturas extremas, ocorre desconexão do PSII do complexo coletor de luz (LHCII), seguido pela migração do PSII da região do grana para a lamela. Assim, como estratégia de se evitar a fotoinibição ou fotodestruição, tanto o NADPH, o ATP, como os elétrons seriam desviados para rotas alternativas, num processo de fotorrespiração, a fim de se manter a estabilidade do processo fotoquímico. A fotorrespiração seria o processo de defesa que evitaria a fotoinibição, sobretudo em plantas $\mathrm{C}_{3}$ (Hall \& Rao, 1994), dissipando o excesso de ATP e NADPH, gerando $\mathrm{CO}_{2}$ interno para a manutenção da atividade da Rubisco e consumindo oxidantes fortes como $\mathrm{H}_{2} \mathrm{O}_{2}$ pela ação de catalases (Lorimer \& Andrews, 1981; Lüttge et al., 1996).

\subsubsection{Condutância Estomática}

Ao analisar-se a condutância estomática, a possibilidade descrita no item 4.1.2, sobre o excesso de produção de ATP e oxidantes fortes, com conseqüente fotorespiração e aumento de temperatura foliar e transpiração, com respectivo aumento da abertura estomática, ou seja, maior condutância, parece pouco provável, desde que não foi possível notar uma correlação significativa entre a condutância estomática e a intensidade dos danos, pois esta variou de maneira muito intensa mesmo nas plantas 
com folhas sadias no caso de $O$. praelonga em folhas de limão cravo(Figura 11A e B). Geralmente, os estômatos trabalham de maneira a manter a pressão parcial interna de $\mathrm{CO}_{2}$ constante em relação à pressão externa, sendo esta concentração definida pelo balanço entre consumo (fotossíntese) e a reposição (fluxo externo, respiração, fotorrespiração) do $\mathrm{CO}_{2}$ (Ramos \& Grace, 1990). Os dados demonstram uma diminuição da condutância estomática para valores de severidade até $40 \%$ de área foliar lesionada, sendo que após este valor ocorre um incremento nesta variável que passa a ser maior do que nas próprias folhas sadias.

Em relação ao ataque de L. coffeella às folhas de cafeeiro 'Obatã', também não houve variação da condutância estomática em função da intensidade de área foliar lesionada, sendo que esta variável fisiológica manteve-se constante ao longo de toda curva (Figura 12A e B), com valores no patamar de $0,10 \mathrm{~mol} \mathrm{H}_{2} \mathrm{O} \cdot \mathrm{m}^{-2} \cdot \mathrm{s}^{-1}$. Em parte, isto pode ser explicado em função do centro de origem do cafeeiro e as adaptações que a espécie possui, permitindo sua permanência em diversos ambientes; tais como adaptações fisiológicas que lhe permitem reduzir a taxa respiratória e maximizar o ganho de carbono (Kitajima, 1994; Ueda et al., 2000; Boardman, 1977).

Estes resultados permitem concluir não ser esta variável fisiológica adequada para correlacionar com lesões em folhas causadas por insetos sugadores ou mastigadores. 

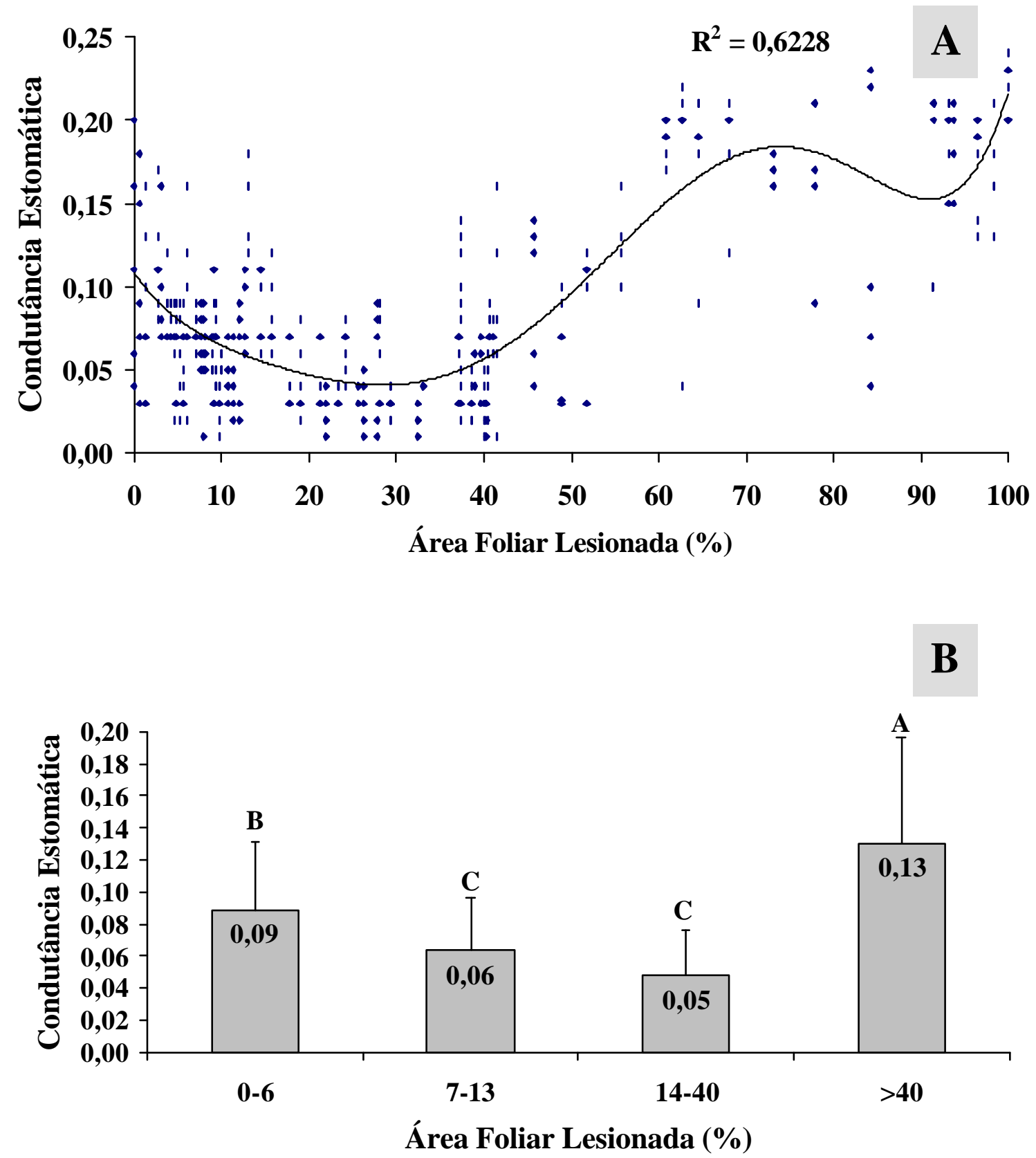

Figura 11 - Efeito da área foliar lesionada (0 a 100\%) por O. praelonga sobre a condutância estomática $\left(\mathrm{mol} \mathrm{H}_{2} \mathrm{O} \cdot \mathrm{m}^{-2} \cdot \mathrm{s}^{-1}\right.$ ) (A) e efeito da intensidade de infestação de $O$. praelonga em quatro intervalos na condutância estomática em folhas de limão cravo (B). Tratamentos seguidos da mesma letra não diferem entre si, pelo teste de Tukey, ao nível de 5\% de probabilidade. 

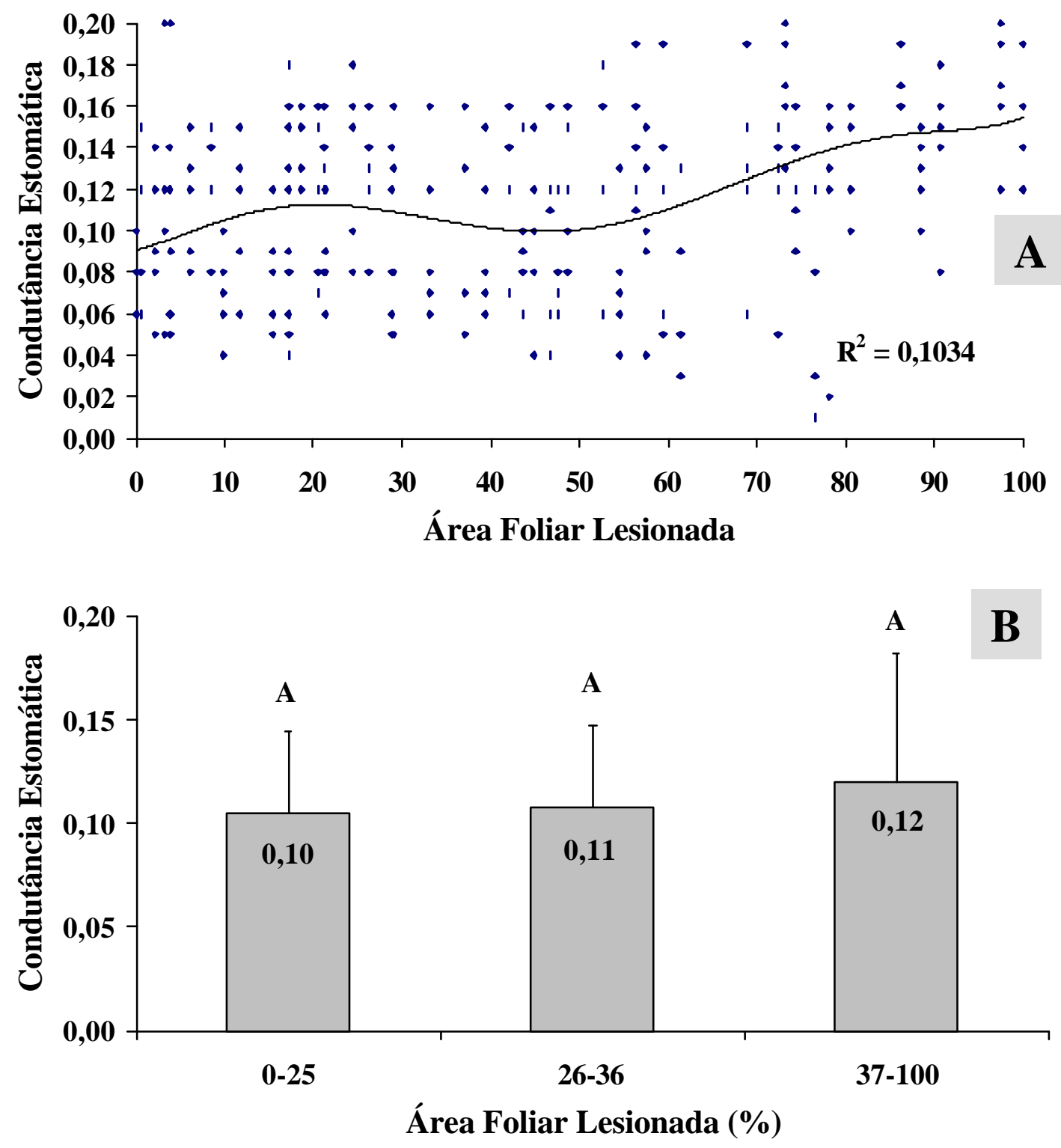

Figura 12 - Efeito da área foliar lesionada (0 a 100\%) por L. coffeella sobre a condutância estomática $\left(\mathrm{mol} \mathrm{H}_{2} \mathrm{O} \cdot \mathrm{m}^{-2} \cdot \mathrm{s}^{-1}\right)$ (A) e efeito da intensidade de infestação de $L$. coffeella em três intervalos na condutância estomática em folhas de café 'Obatã' (B). Tratamentos seguidos da mesma letra não diferem entre si, pelo teste de Tukey, ao nível de 5\% de probabilidade 


\subsubsection{Transpiração foliar}

Angelocci (2000) e von Caemmerer (2003) relataram que a condutância estomática pouco tem a ver com a capacidade fotossintética das plantas e que esta, na verdade, deve-se à capacidade de difusão de $\mathrm{CO}_{2}$ no mesofilo foliar e na fluidez das membranas ao facilitar a passagem deste gás; entretanto a condutância estomática possui estreita relação com a transpiração foliar, uma vez que a porta de saída da água nas folhas é o estômato.

Isto foi observado na presente pesquisa, uma vez que mesmo não havendo uma correlação significativa entre transpiração e intensidade de danos (área foliar lesionada), com grande variação mesmo nas folhas sadias, a transpiração foliar foi sempre maior nos intervalos onde a condutância estomática foi maior, com ênfase no caso da de $O$. praelonga em folhas de limão cravo (Figura 13A e B).

Para L. coffeella em folhas de cafeeiro, também não foi possível estabelecer uma correlação distinta entre transpiração foliar e intensidade de área foliar lesionada, resultado já esperado, devido as características adaptativas da planta (Kitajima, 1994; Ueda et al., 2000; Boardman, 1977). e pela constância da condutância estomática. Neste caso, os valores encontrados foram de 1,0 a 1,1 $\mathrm{mmol} \mathrm{H}_{2} \mathrm{O} \cdot \mathrm{m}^{-2} \cdot \mathrm{s}^{-1}$ (Figura 14A e B).

Portanto, à semelhança da condutância estomática, também a transpiração foliar não se mostrou como um parâmetro adequado para correlação com danos pelos dois tipos de insetos analisados. 

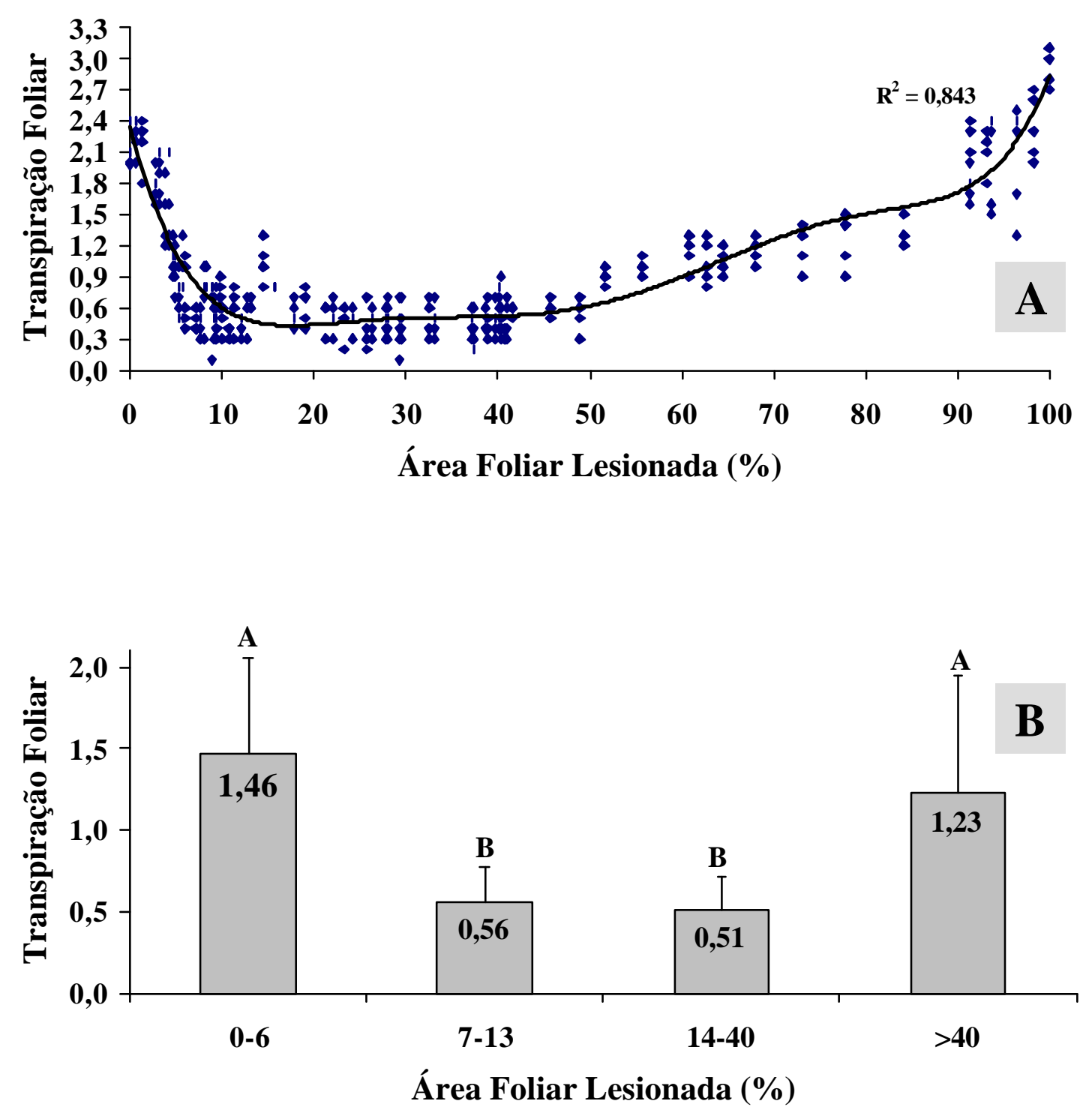

Figura 13 - Efeito da área foliar lesionada (0 a 100\%) por O. praelonga sobre a transpiração foliar (mmol $\mathrm{H}_{2} \mathrm{O} \cdot \mathrm{m}^{-2} \cdot \mathrm{s}^{-1}$ ) (A) e efeito da intensidade de infestação de $O$. praelonga em quatro intervalos na transpiração foliar em folhas de limão cravo (B). Tratamentos seguidos da mesma letra não diferem entre si, pelo teste de Tukey, ao nível de $5 \%$ de probabilidade 

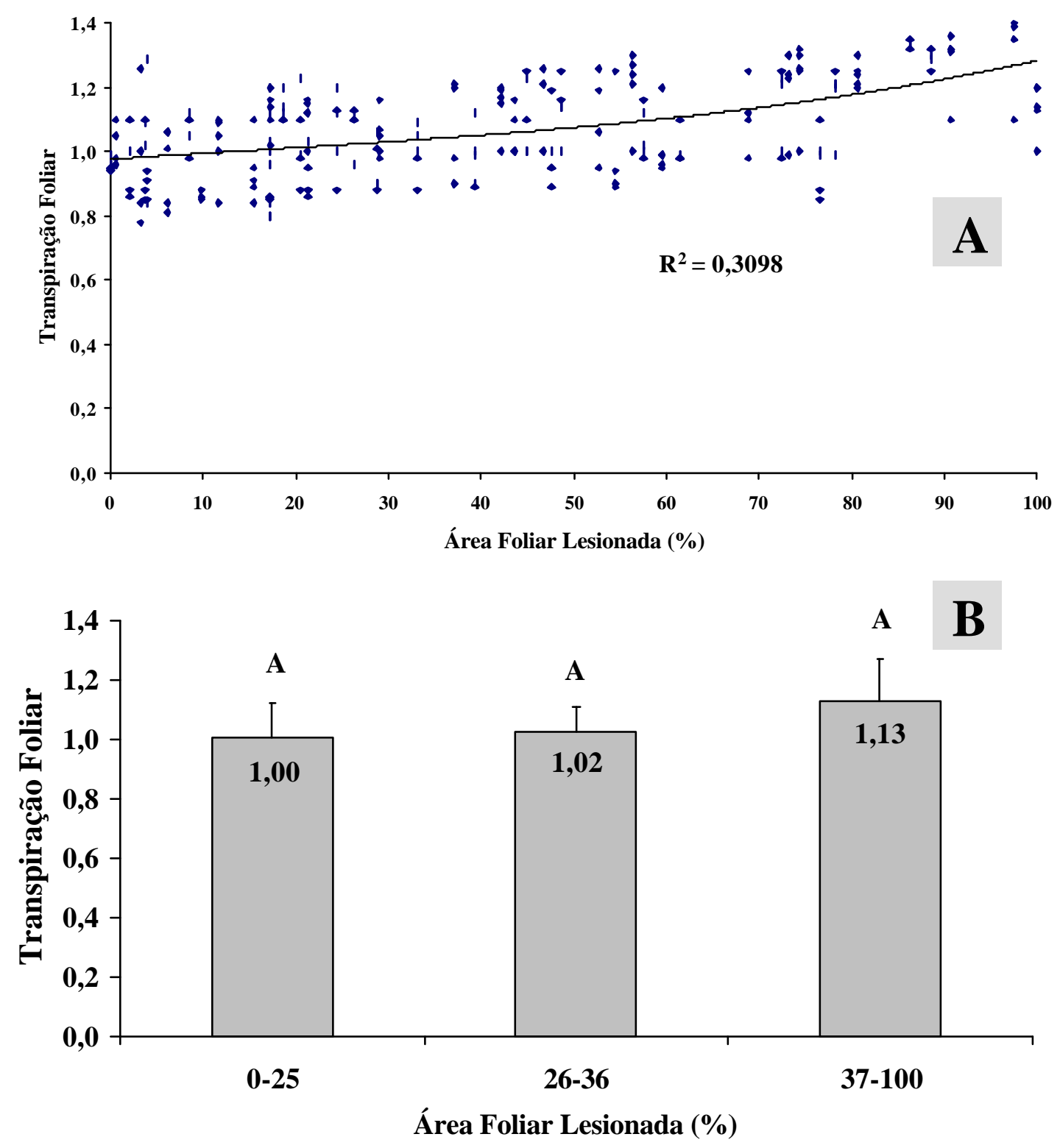

Figura 14 - Efeito da área foliar lesionada (0 a 100\%) por L. coffeella sobre a transpiração foliar $\left(\mathrm{mmol} \mathrm{H} \mathrm{O} \cdot \mathrm{m}^{-2} \cdot \mathrm{s}^{-1}\right)(\mathrm{A})$ e efeito da intensidade de infestação de L. coffeella em três intervalos na transpiração foliar em folhas de cafeeiro 'Obatã' (B). Tratamentos seguidos da mesma letra não diferem entre si, pelo teste de Tukey, ao nível de 5\% de probabilidade 


\subsubsection{Temperatura Foliar}

No caso de $O$. praelonga em limão cravo, não houve diferenças fisiológicas significativas nos valores de temperatura foliar para os intervalos descritos, sendo que a menor temperatura foi registrada nas plantas sadias, de $27,6^{\circ} \mathrm{C}$, e a maior em plantas com área foliar lesionada superiores, a $40 \%$, de $29,3^{\circ} \mathrm{C}$, com variação de $\pm 1^{\circ} \mathrm{C}$ (Figura 15).

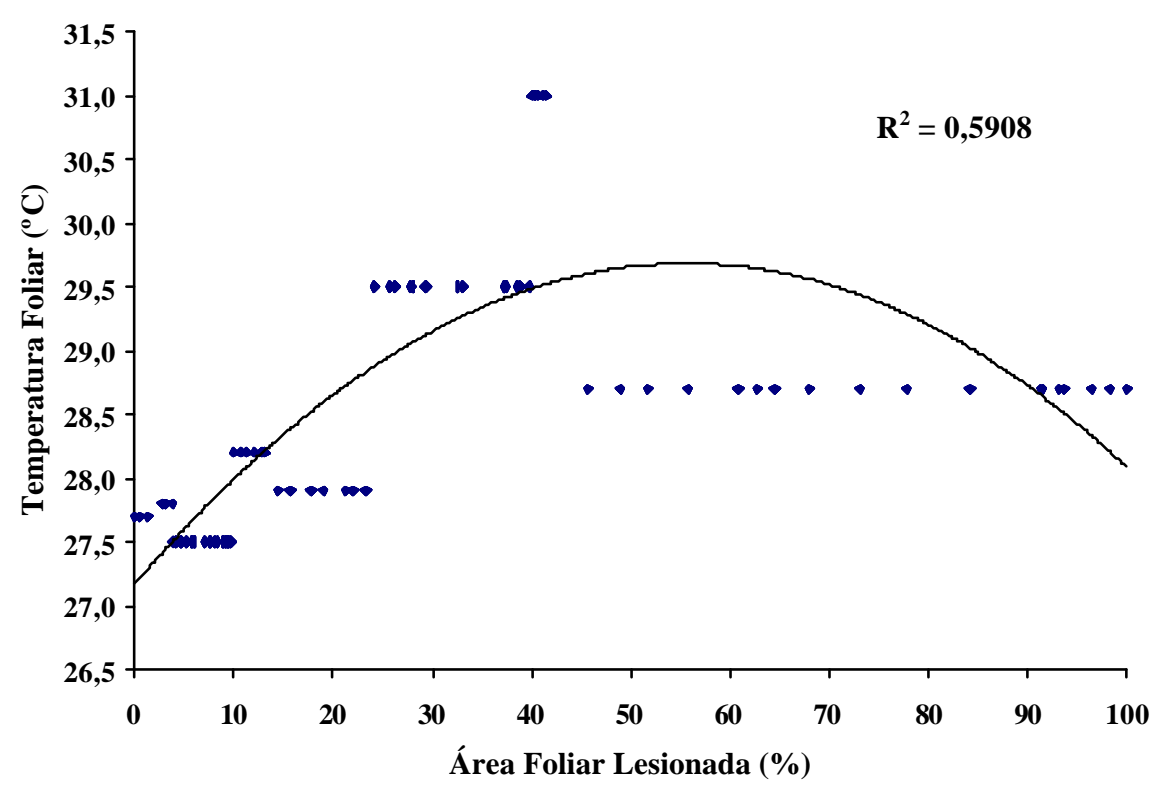

Figura 15 - Efeito da área foliar lesionada (0 a 100\%) por O. praelonga sobre a temperatura foliar $\left({ }^{\circ} \mathrm{C}\right)$ de folhas de limão cravo

Segundo Kriedmann (1968) a temperatura ótima para assimilação de $\mathrm{CO}_{2} \mathrm{em}$ algumas espécies de citros está entre 15 e $20^{\circ} \mathrm{C}$ quando em ambiente seco, com alto déficit de pressão de vapor (baixa umidade relativa do ar) e entre 20 e $30^{\circ} \mathrm{C}$ em ambientes onde a umidade relativa está acima de 80\%; no entanto, este limiar de temperatura pode oscilar em torno de $3^{\circ} \mathrm{C}$, para mais ou para menos, dependendo da variedade ou espécie, bem como da saturação da umidade do ambiente e diminuição do 
diferencial de pressão de vapor, como no caso em questão. Assim, dificilmente a temperatura foliar estaria afetando fisiologicamente a assimilação de $\mathrm{CO}_{2}$.

No caso de L. coffeella em folhas de café, também não houve correlação entre intensidade de área foliar lesionada e temperatura foliar, sendo que esta manteve-se constante ao longo de toda a curva, com valores médios de $34 \pm 0,25^{\circ} \mathrm{C}$ (Figura 16); esta constância ocorreu em função do café possuir espessas paredes celulares nos tecidos da epiderme e da hipoderme que atuam como um filtro capaz de modificar a radiação direta em luz difusa, minimizando o efeito da radiação intensa (Larcher, 2000); este filtro deve auxiliar na manutenção da temperatura foliar e transpiração, uma vez que o aumento da radiação provoca um aumento na temperatura da folha (Kumar \& Tieszen, 1980).

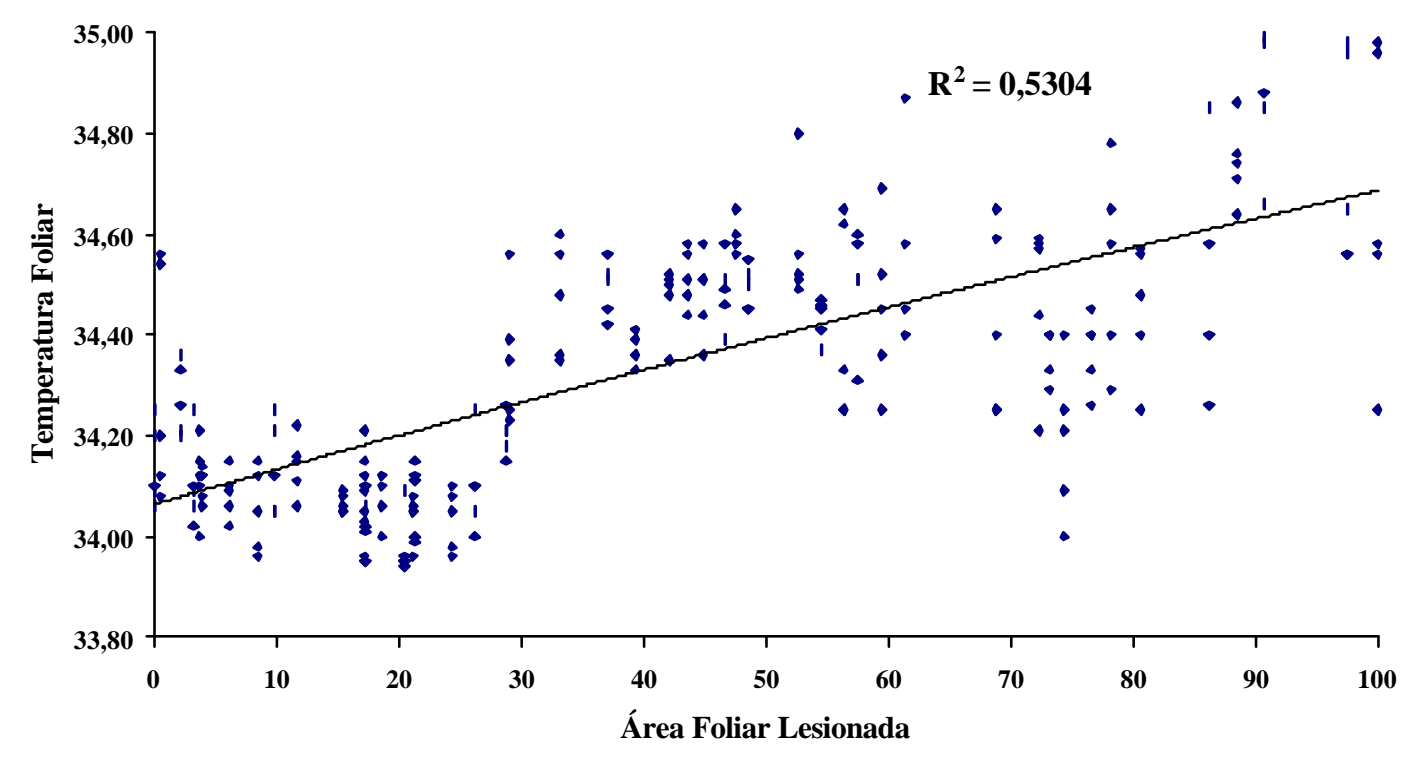

Figura 16 - Efeito da área foliar lesionada (0 a 100\%) por L. coffeella sobre a temperatura foliar $\left({ }^{\circ} \mathrm{C}\right)$ de folhas de cafeeiro 'Obatã' 


\subsubsection{Concentração interna de $\mathrm{CO}_{2}$, eficiência instantânea de carboxilação e eficiência intrínseca de $\mathrm{CO}_{2}$}

A análise conjunta dos dados demonstrou que em condições de abertura plena dos estômatos (valores iniciais e finais da curva) nas folhas de limão cravo, ocorrem uma maior entrada de $\mathrm{CO}_{2}$, propiciando uma maior concentração interna de gás carbônico no mesofilo foliar, sendo que estes valores variaram bastante ao longo da curva, não estabelecendo uma tendência muito definida em relação à área foliar lesionada, ocorrendo também uma maior perda de água (transpiração foliar); no entanto, para o primeiro intervalo ( 0 a $6 \%$ de área foliar lesionada) ocorreu a maior assimilação de gás carbônico, revelando a integridade do processo fotossintético; já no ponto oposto da curva, em áreas lesionadas superiores a 40\%, apesar da completa abertura estomática e a manutenção dos níveis médios de temperatura foliar e da concentração interna de $\mathrm{CO}_{2}$ (Figura 17), a transpiração manteve-se alta e a taxa fotossintética caiu em alguns casos a valores negativos, demonstrando que houve diminuição da eficiência instantânea de carboxilação da rubisco (razão fotossíntese/concentração interna de $\mathrm{CO}_{2}$ ) (Figura 18A), que pode ter ocorrido devido à combinação da taxa de ribulose com a redução da quantidade ou atividade da enzima de carboxilação (Correia et al., 1999), e também diminuição da eficiência intrínseca do uso da água em função da irradiância (relação fotossíntese/condutância estomática) (Carelli et al., 1999) (Figura 18B). 


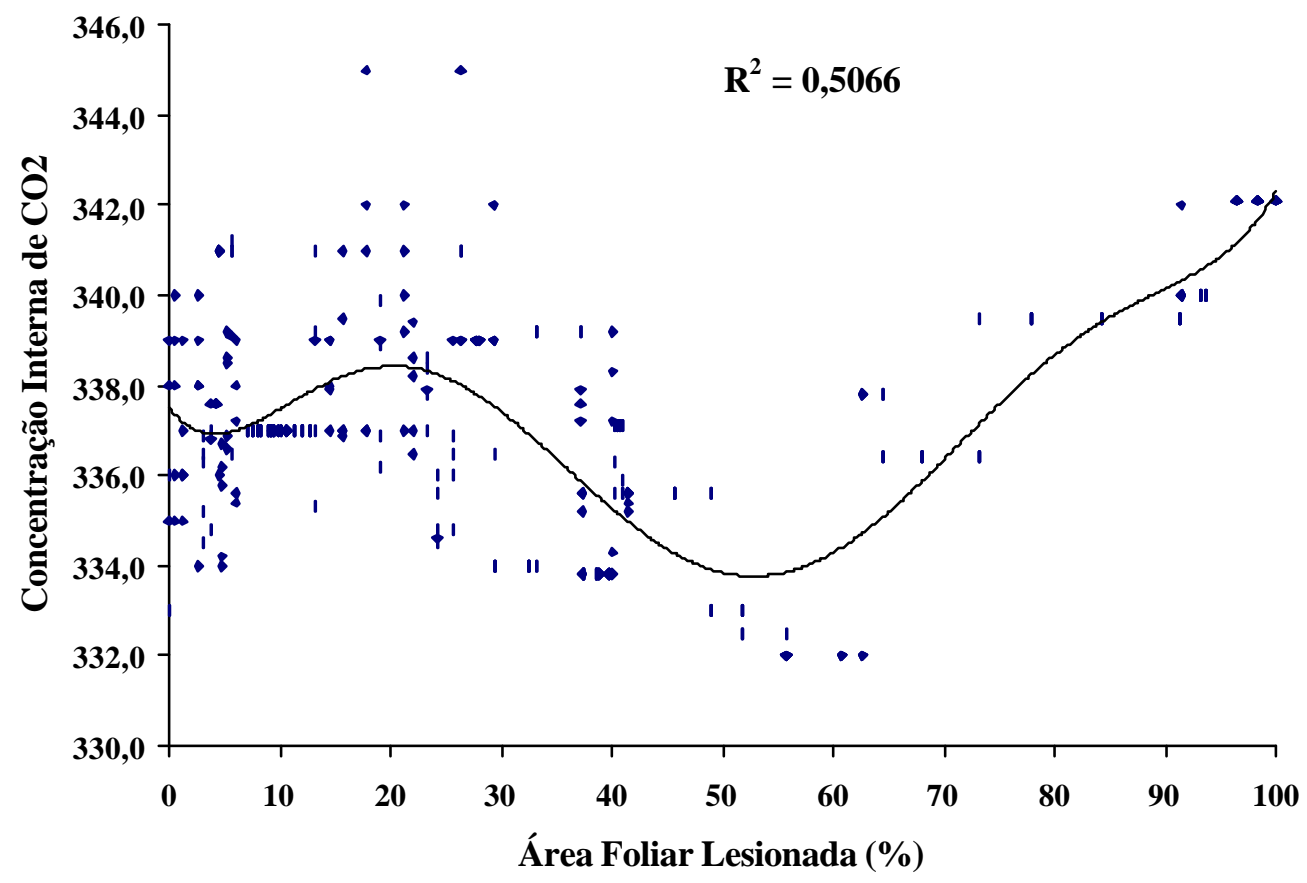

Figura 17 - Efeito da área foliar lesionada (0 a 100\%) por O. praelonga sobre a concentração interna de $\mathrm{CO}_{2}\left(\mathrm{mmol} \cdot \mathrm{mol}^{-1}\right)$ em folhas de limão cravo 


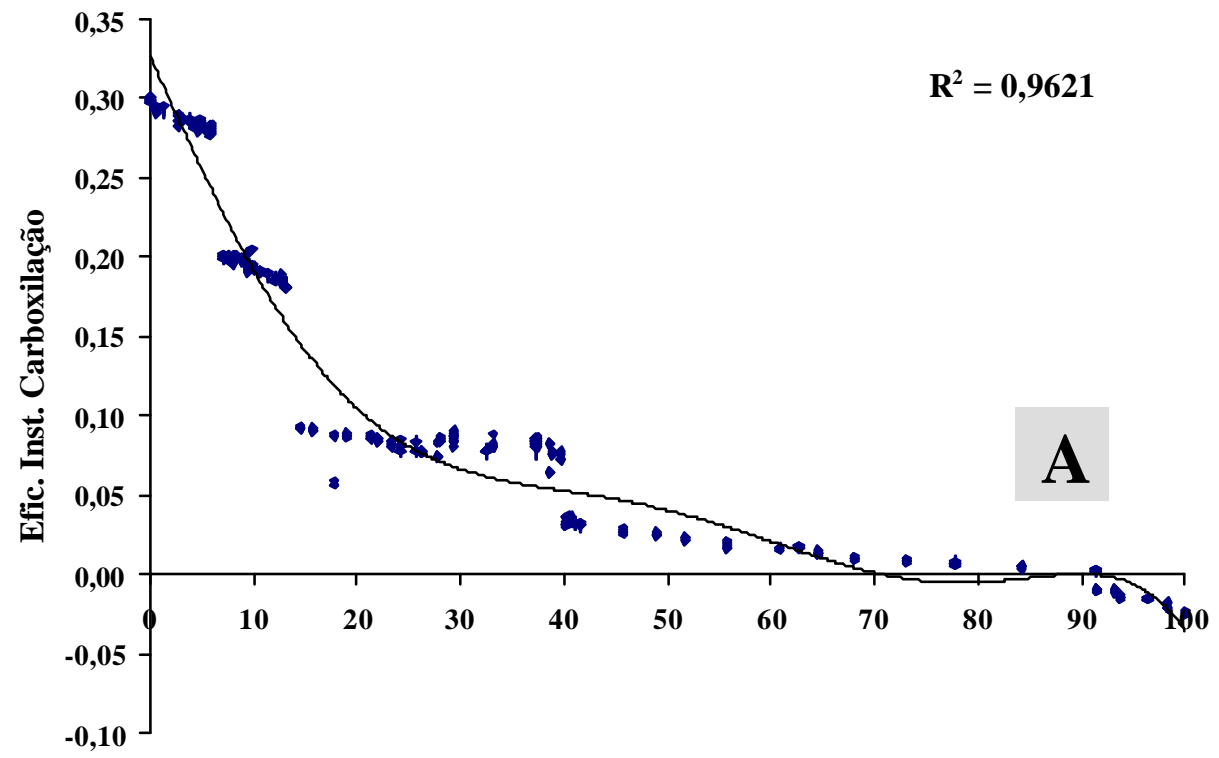

Área Foliar Lesionada (\%)

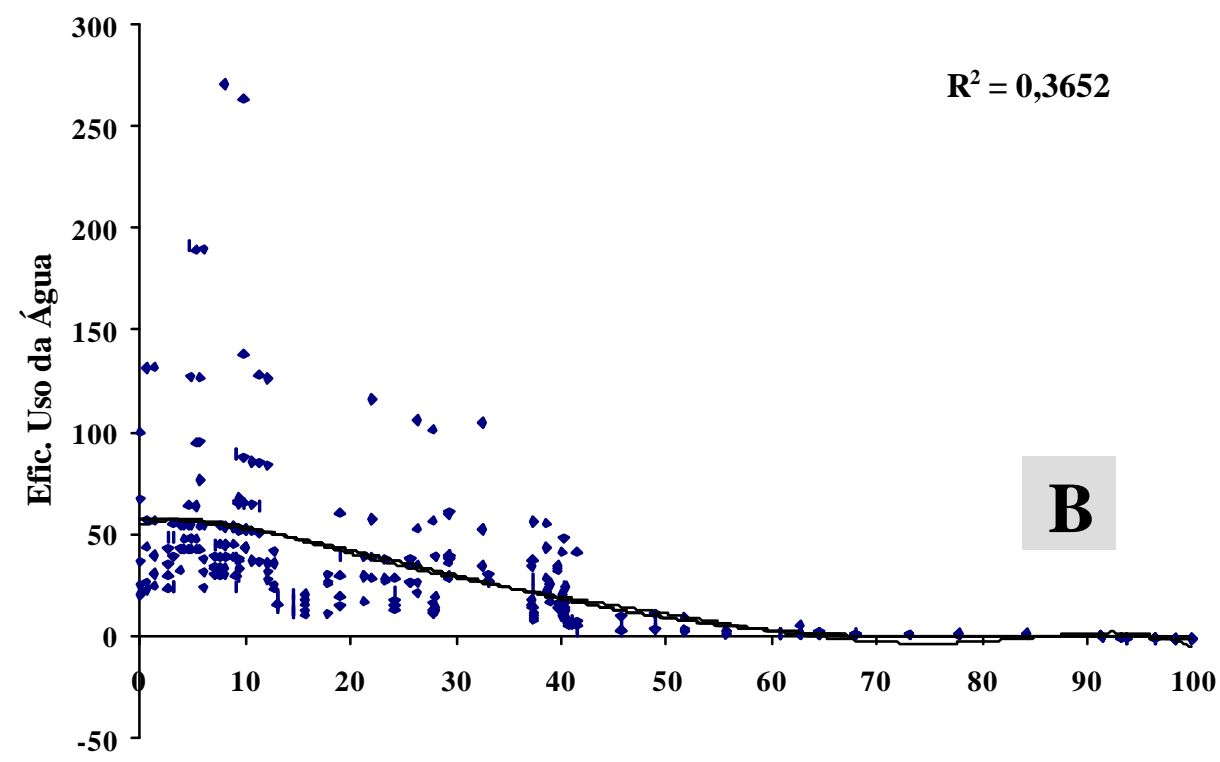

Área Foliar Lesionada (\%)

Figura 18 - Efeito da área foliar lesionada (0 a 100\%) por O. praelonga na eficiência instantânea de carboxilação (A) e na eficiência instantânea do uso da água (B) em folhas de limão cravo 
A ação de $O$. praelonga no PSI (Fotossistema I - fase bioquímica) não foi definida, sendo que uma possibilidade seria a maior oxigenação, em detrimento da carboxilação da rubisco, ou mesmo efeitos deletérios múltiplos ou isolados sobre vários aspectos bioquímicos do sistema, como inativação de enzimas em função de alterações de $\mathrm{pH}$ ou componentes tóxicos, ou mesmo alterações na taxa de regeneração da ribulose ou decréscimo da atividade da rubisco (O’Toole et al., 1977). Assim, novos experimentos devem ser realizados nesta direção visando à elucidação desta dúvida.

De acordo com os argumentos já citados relativos a adaptação do cafeeiro à diversos ambientes, tem-se que como conseqüência da não variação da condutância estomática e da transpiração foliar ao longo da curva, a concentração interna de $\mathrm{CO}_{2}$ também não apresentou correlação com a área foliar lesionada, mantendo-se em valores médios de $337 \pm 3,5$ ppm de $\mathrm{CO}_{2}$ (Figura 19), sendo que a concentração interna de $\mathrm{CO}_{2}$ mostrou uma ligeira alta, não significativa, para valores de área foliar lesionada superiores a 80\%; neste caso, há a hipótese de ruptura da epiderme e/ou hipoderme devido à necrose do tecido foliar, constituindo assim um ponto de entrada do gás contido sob pressão na câmara de leitura de maneira passiva, sem resistência, impossível de ser impedida ou controlada.

Mesmo mantendo a concentração interna de $\mathrm{CO}_{2}$ constante, é possível observar que L. coffeella afetou a fotossíntese, promovendo a diminuição deste parâmetro, de maneira não linear em relação ao aumento da área foliar lesionada, que pode ter sido reduzida no tecido visualmente sadio e fisiologicamente comprometido devido à combinação da taxa de ribulose com a redução da quantidade ou atividade da enzima de carbolixação (Correia et al., 1999); conseqüentemente, ao aplicarem-se as relações matemáticas para cálculo da eficiência instantânea de carboxilação da rubisco (razão fotossíntese/concentração interna de $\mathrm{CO}_{2}$ ) e eficiência intrínseca do uso da água em função da irradiância (relação fotossíntese/condutância estomática) (Carelli et al., 1999), nota-se a diminuição destas duas relações (Figura 20A e B); contudo não se pode deixar de considerar que devido ao hábito alimentar mastigador do inseto, ao ingerir o parênquima paliçádico das folhas (Cárdenas Murillo \& Orozco Castaño, 1983; Ramiro et al. 2003), ele promove a destruição de pigmentos antena (responsáveis pela captação 
de luz) do conjunto fotossintético, além de consumir outras enzimas ligadas ao mecanismo fotossintético, sendo este o maior dano causado pelo inseto ao processo fotossintético, ou seja, inativação da fase fotoquímica da fotossíntese. Também conforme já abordado anteriormente, há ainda o pequeno halo amarelado em torno da área necrosada (item 4.1.1), e estes tecidos adjacentes também sofrem influência direta de metabólitos tóxicos provenientes da saliva ou excrementos do inseto e podem afetar, por exemplo, a transposição de elétrons do PS II para o PS I, uma vez que estes centros de reação ficam espacialmente separados nos cloroplastos, comprometendo assim a fase bioquímica da fotossíntese (Taiz \& Zeiger, 2004).

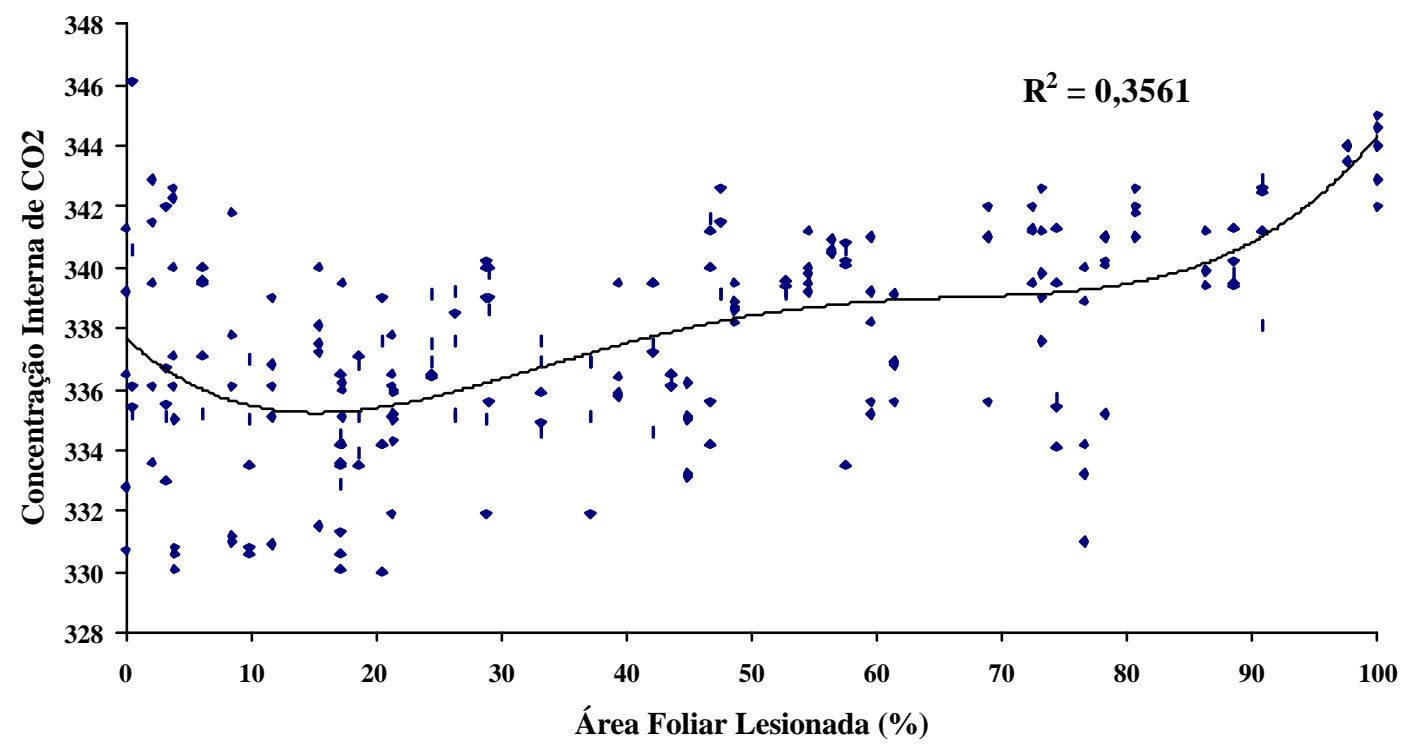

Figura 19 - Efeito da área foliar lesionada (0 a 100\%) por L. coffeella sobre a concentração interna de $\mathrm{CO}_{2}\left(\mathrm{mmol}^{\mathrm{mol}}{ }^{-1}\right)$ em folhas de cafeeiro 'Obatã' 

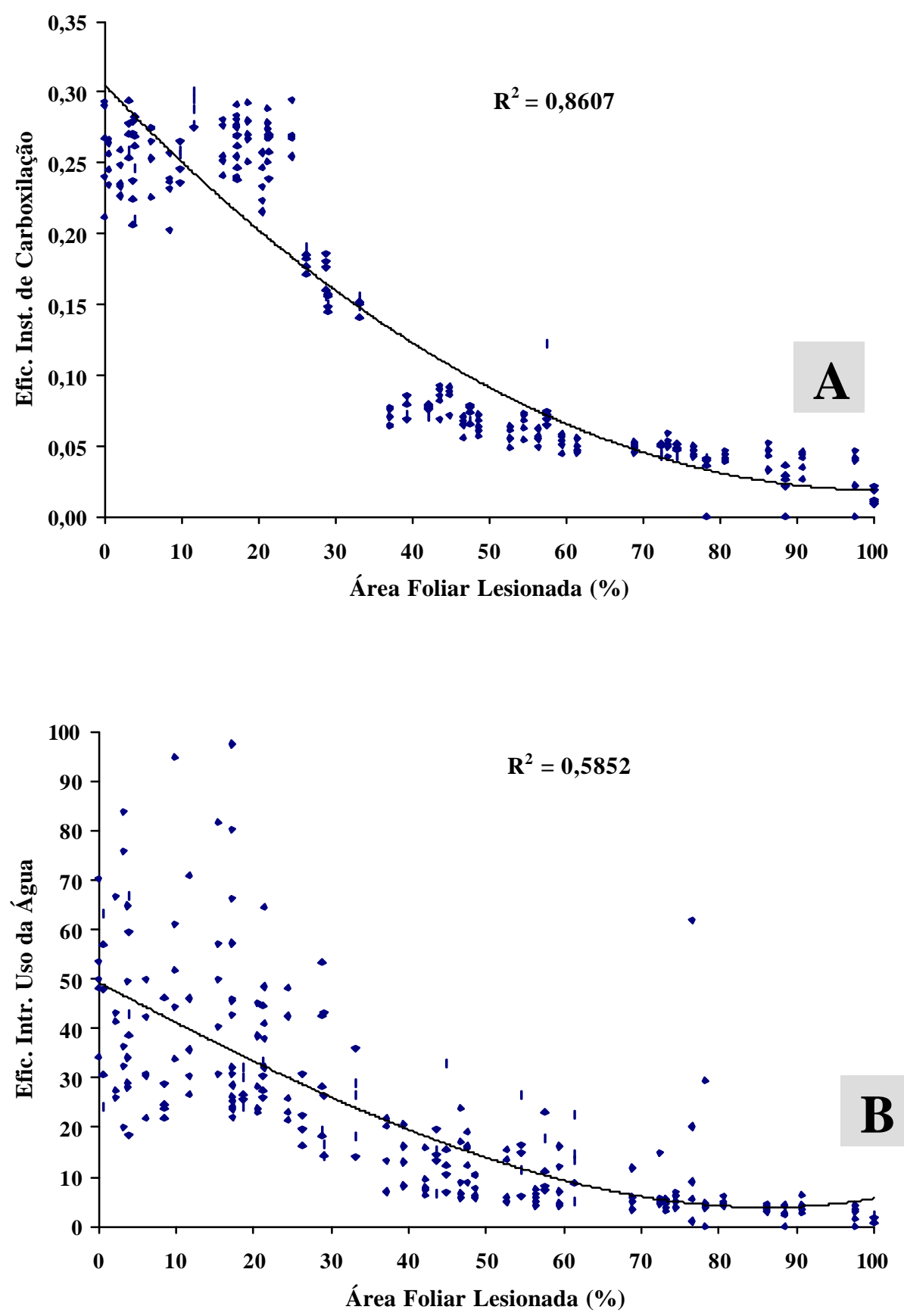

Figura 20 - Efeito da área foliar lesionada (0 a 100\%) por L. coffeella na eficiência instantânea de carboxilação (A) e na eficiência intrínseca de uso da água (B) em folhas de cafeeiro 'Obatã' 


\subsection{7 - Considerações finais}

Os resultados obtidos com as diferentes variáveis fisiológicas permitem a conclusão de que para $O$. praelonga o nível de controle está abaixo da faixa de 7 a $13 \%$ de área foliar lesionada, sobre folhas de limão cravo. É evidente que o valor correto de nível de controle deve ser determinado observando-se as características ecológicas que afetam a praga (temperatura e umidade, entre outras) e também questões econômicas do ano (valor do produto a ser comercializado). Desta maneira, quando a praga estiver presente, e o preço da laranja estiver muito baixo, o controle da praga poderá ser realizado quando ocorrer uma infestação próxima a $13 \%$ de área foliar lesionada. Quando o preço estiver favorável, o produtor pode optar por controlar a infestação com nível de infestação menor $(<7 \%)$.

Do ponto de vista ecológico, desde que o inseto se desenvolve melhor em ambientes mais frios e secos (Prates \& Pinto, 1987) e apresenta a capacidade de suportar grandes variações climáticas (Puzzi \& Camargo, 1963), o nível de controle abaixo de $7 \%$ de área foliar infestada poderia ser adotado em pomares instalados em locais que apresentem a combinação de baixas temperaturas e baixas umidades, sendo que em locais onde ocorrem altas umidades e temperaturas elevadas, pode ocorrer a regulação populacional da praga por agentes naturais de controle (Gomes, 1954; Viegas et al., 1995), e neste caso a praga seria menos prejudicial.

No caso de $O$. praelonga, é fundamental ainda a adequação de um plano de amostragem da praga, semelhante aos desenvolvidos por Parra (1975) para bichomineiro em cafeeiro, por Silva (1995) e Moscardi, (1983) na cultura da soja para a lagarta Anticarsia gemmatalis Hubner, 1818 (Lepidoptera: Noctuidae), abordando de maneira clara e objetiva os seguintes fatores: a) número de plantas amostradas no talhão, sendo também relevante a posição destas plantas dentro do talhão e a forma como será o feito a caminhamento dentro dele para a amostragem destas plantas; b) número de folhas amostradas por planta; c) distribuição das folhas amostradas na copa das árvores (terço basal, mediano e superior) uma vez que cada porção da árvore contribui de maneira distinta na assimilação de $\mathrm{CO}_{2}$ e na partição de assimilados (Miele, 1989; Proietti et al., 2000), bem como o fato de que ocorrem grandes variações temporal e espacial no uso de 
reservas; d) geoposicionamento destas plantas e folhas em relação à luz (mais a sombra ou mais ao sol); e) reconhecimento qualitativo e quantitativo dos inimigos naturais que atuam na regulação populacional da praga.

Também é preciso uma maneira de se traduzir ao agricultor os resultados obtidos, como a confecção de escalas diagramáticas de danos baseando-se em James (1974) e Horsfall \& Barratt (1945).

Outro fator relevante é a necessidade do agricultor em inspecionar também plantas ornamentais, que sempre compõem o projeto paisagístico da fazenda, e que por serem hospedeiros naturais da praga, acabam servindo de inóculo no processo de contaminação dos pomares.

Também é necessário adotar táticas de manejo que permitam manter o equilíbrio natural do agroecossistema, uma vez que a supressão de inimigos naturais leva a reinfestação do pomar pela cochonilha, além da ocorrência de novas pragas quando o controle é feito de maneira inadequada (Benvenga et al., 2000, referido em Prates, 2002).

Outro ponto relevante diz respeito à ocorrência do fungo Capnodium sp., também conhecido como fumagina, que se desenvolve no material açucarado exsudado pela cochonilha ('honeydew") (Gomes, 1954). Ele não possui ação fitopatogênica direta, porém ao encobrir as folhas afeta a fotossíntese e a transpiração das plantas (Guirado et al., 2001; entre outros autores). Via de regra, os produtores se baseiam no aparecimento deste fungo como referencial para adotar alguma medida de controle e, na maioria dos casos, a ocorrência do fungo se manifesta quando a população da praga já se encontra elevada, em grandes colônias, com nível de infestação muitas vezes superior a $20 \%$ de área foliar lesionada (Silva-Filho et al., 2004). Assim, é necessário conscientizar o agricultor de que a amostragem deve ser feita a partir da ocorrência da praga e não do fungo, visando uma melhor estratégia de controle.

Para o bicho-mineiro dos cafeeiros, o nível de controle está aquém da faixa de 26 a 36\% de área foliar lesionada. Os mesmos cuidados na amostragem para $O$. praelonga devem ser tomados com relação a $L$. coffeella, devendo ser amostradas folhas jovens, porém maduras, totalmente expandidas, preferencialmente no terço superior da 
copa e à partir do segundo e terceiro internódios à se contar do ápice; devendo -se ainda levar em consideração o fato de que na época seca os prejuízos causados pela praga são menores em relação à época chuvosa (Parra, 1981). Assim, como nível de controle, poderiam ser considerados os menores valores da faixa (26\%) para a época chuvosa e os maiores valores (36\%) para a época seca.

Deve ser levado em consideração ainda, o fato de que estas leituras de fotossíntese e outras variáveis fisiológicas vegetais foram feitas em condições de laboratório e especificamente com limão cravo (Citrus limonia L.) para as infestações de O. praelonga e em mudas de cafeeiro 'Obatã' no caso de L. coffeella, dessa maneira, seria prudente para a confirmação do modelo, novas leituras em citros, com variedades copas enxertadas sobre este porta-enxerto, bem como, em função do avanço da morte súbita dos citros e a iminente troca dos porta-enxertos atuais por outros não suscetíveis a esta doença, também o estudo da interação desta praga com os novos cavalos selecionados. O mesmo é válido para as plantas de café, uma vez que segundo Engel e Poggiani (1991), a eficiência fotossintética esta ligada ao teor de clorofila das plantas, e Lee (1988) relatou que diversos estudos realizados evidenciaram que este eor varia muito entre as espécies, assim como entre genótipos de uma mesma espécie

Portanto, a fotossíntese, dentre as variáveis estudadas, se mostrou a mais adequada para correlacionar danos de insetos sugadores e mastigadores, se apresentando como um parâmetro adicional para programas de Manejo Integrado de Pragas (MIP), para determinação do nível de dano (ou de controle) de pragas. 


\section{CONCLUSÕES}

- De acordo com os resultados obtidos, com base nas leituras de fotossíntese e demais variáveis fisiológicas vegetais analisadas (condutância estomática, transpiração foliar, concentração interna de $\mathrm{CO}_{2}$, temperatura foliar), o nível de dano de Orthezia praelonga Douglas, 1891, em mudas de limão cravo, situa-se na faixa de 7 a $13 \%$ de área foliar lesionada, sendo que para Leucoptera coffeela (Guérin-Menneville (1842), o valor ficou entre 26 e $36 \%$;

- A fotossíntese se mostrou como parâmetro mais adequado para tal determinação;

- O nível de controle, para ambas as pragas, de hábitos alimentares diferentes (sugadores e mastigadores), está aquém destes valores, podendo ser variável, dependendo da época do ano e necessitando de avaliações de campo;

- A metodologia de laboratório se mostrou válida para insetos-pragas sugadores e mastigadores, embora os fotossistemas tenham sido afetados de forma diferente, dependendo do hábito alimentar da praga. 


\section{REFERÊNCIAS BIBLIOGRÁFICAS}

ABO-FOULS, S.; RASKIN, V.I.; SZTEJNBERG, A.; MARDER, J.B. Disruption of chlorophyll organization and function in powdery mildew-disease cucumber leaves and its control by hiperparasite Ampelomyces quisqualis. Phytopathology, v.86, p.195-199, 1996.

AGRIOS, G. N. Plant pathology 4.ed. San Diego: Academic Press, 1997. 635p.

ANGELOCCI, L.R. Processos de transferência no sistema planta-atmosfera. Piracicaba: CALQ, 2000. 112p.

ATIQUE, C.C. Comparação entre eficiência de mátodos de amostragem para determinação de índices de infestação do bicho-mineiro Perileucopter cofeella (Guérin-Mèneville, 1842) In: CONGRESSO BRASILEIRO DE PESQUISAS CAFEEIRAS, 7., Araxá, 1979. Resumos. Rio de Janeiro, IBC;GERCA, 1949. p.141-145.

BAILISS, K.W. Infection of cucumber cotyledons by cucumber mosaic virus and the participation of chlorophylase in the development of chlorotic lesions. Annals of Botany, v.34, p.647-655, 1970. 
BASSANEZI, R. B. Efeito de doenças foliares na eficiência fotossintética do feijoeiro (Phaseolus vulgaris L.) como contribuição na avaliação de danos. Piracicaba, 2000. 233p. Tese (Doutorado) - Escola Superior de Agricultura "Luiz de Queiroz", Universidade de São Paulo.

BASTIAANS, L. Ratio between virtual and visual lesion size as a measure to describe reduction in leaf photosynthesis of rice due to leaf blast. Phytopathology, v.81, n.6, p.611-615, 1991.

BEARDSLEY JUNIOR, J.W.; GONZALES, R.H. The biology and ecology of armored scales. Annual Review of Entomology, v.20, p.47-73, 1975.

BERGAMIN FILHO, A.; LOPES, D. B.; AMORIM, L.; GODOY, C. V.; BERGER, R. D. Avaliação de danos causados por doenças de plantas. Revisão Anual de Patologia de Plantas, v.3, p.133-184, 1995.

BERNACCHI, C.J.; SINGSAAS, E.L.; PIMENTEL, C; PORTIS JUNIOR, A.R.; LONG, S.P. Improved temperature response functions for models of Rubisco-limited photosynthesis. Plant, Cell and Environment, v.24, n.2, p.253-259, 2001.

BOARDMAN, N.K. Comparative photosynthesis of sun and shade plants. Annual Review and Plant Physiology, v.28, p.355-377, 1977.

BOBADILlA, D.; VARGAS, H.; ES, P.G.; SEPÚlVEDA, G.; MENDONZA, R. Enemigos naturales de las conchuelas móviles, Orthezia spp. (Homoptera: Ortheziidae), detectados en el norte de Chile. Idesia, v.16, p.117-123, 1999.

BOOTE, K. J.; JONES, J. W.; MISHOE; J. W.; BERGER, R. D. Coupling pests to crop growth simulations to predict yield reductions. Phytopathology, v.73, p.1581$1587,1983$. 
CAEMMERER, S.; LAWSON, T.; OXBOROUGH, K.; BAKER, N.R., ANDREWS, T.J.; RAINES, C.A. Stomatal conductance does not correlate with photosynthetic capacity in transgenic tobacco with reduced amounts of rubisco. Journal of Experimental Botany, v.55, n.400, p.1157-1166, 2004.

CÁRDENAZ MURILLO, R.; OROZCO CASTAÑO, F.J. Caracterzación histomorfologica del daño de minador de las hojas del cafeto (Leucoptera coffeella G. M.) en seis materiales de Coffea. Cenicafé, v.34, n.2, p.37-43, 1983.

CARELLI, M.L.C.; FALH, J.L.; TRIVELIN, P.C.O.; QUEIROZ-VOLTAN, R.B. carbon isotope discrimination and gas exchange in Coffea species grown under diferent irradiance regimes. Revista Brasileira de Fisiologia Vegetal, v.11, n.2, p.63-68, 1999.

CARTER, W. Insects in relation to plant disease. New York: Interscience, 1962. 705p.

CARVALHO, R.S.; NASCIMENTO, A.S. do; SANCHES, N.F. Controle da ortezia dos citros. Cruz das Almas: Embrapa, CPNF, 1998. 15p. (Embrapa. CPNF. Circular Técnica, 31).

CASSINO, P.C.R.; LIMA, A.F. de; RACCA FILHO, F. Orthezia praelonga Douglas, 1891 em plantas cítricas no Brasil (Homoptera, Ortheziidae). Arquivos da Universidade Federal do Rio de Janeiro, v.14, n.1, p.27-34, 1991.

CASSINO, P.C.R.; PERRUSO, J.C.; NASCIMENTO, F.N. do. Contribuição dos conhecimentos das interações bioecológicas entre Aleirodideos (Homóptera, Aleyrodidae) e Orthezia praelonga Douglas, 1891 (Homóptera, Ortheziidae) no agroecossistema cítrico. Anais da Sociedade Entomológica do Brasil, v.22, n.1, p.209-212, 1993. 
CESNIK, R.; PRATES, H. S.; ALVES, S. B. Controle biológico da cochonilha ortézia. http://www.cati.sp.gov.br/novacati/index.php (20.out.2003)

CORREIA, C.M.; AREAL, E.L.V.; TORRES-PEREIRA, M.S.; TORRES-PEREIRA, J.M.G. Intraspecific variation in sensitivity to ultraviolet radiation in maize grown under field conditions II. Physiological and biochemical aspects. Field Crops Research, v.62, n.2/3, p.97-105, 1999.

COSTA LIMA, A.M. Homópteros. In: COSTA LIMA, A.M. Insetos do Brasil. Rio de Janeiro: E.N.A., 1942. v.3, 327p.

CRUZ, J.D.; MARQUES, O.M.; NASCIMENTO, A.S. Consumo de Orthezia praelonga Douglas, 1891 (Insecta: Ortheziidae) por Oxystyla pulchella Spix, 1827 (Gastropoda: Bulimullidae) em laboratório. Sitientibus, n.20, p.81-88, 1999.

DELIEU, T.; WALKER, D. A.; Polarographic measurement of photosynthetic oxygen evolution by leaf discs. New Phytologist, v.89, p.165-178, 1981.

ENGEL, V.L.; POGGIANI, F. Estudo da concentração de clorofila nas folhas e seu espectro de absorção de luz em função do sombreamento em mudas de quatro espécies florestais nativas. Revista Brasileira de Fisiologia Vegetal, v.3, p.39-45, 1991.

FARQUAR, G. D.; CAEMMERER, S. von. Modeling of photosynthetic response to enviromental conditions. In: LANGE, O. L.; NOBEL, P. S.; OSMOND, C. B.; ZIEGLER, H. (Ed.). Physiological plant ecology II. Berlin: Springer-Verlog, 1982. p.549-587. 
FARQUAR, G.P.; CAEMMERER, S. Von.; BERRY, J. A. A biochemical model of photosynthetic $\mathrm{CO}_{2}$ assimilation in leaves of C3 species. Planta, v.149, p.78-90, 1980.

FERNANDES, O.A., Ecologia dos insetos. In: GUEDES, J.V.C; COSTA, I.D.; CASTIGLiOni, E. Bases e técnicas do manejo de insetos. Santa Maria: UFMS/CCR/DFS; Pallotti, 2000. cap.3, p.51-58.

FONSECA, J.P. da. O "bicho-mineiro" das folhas do cafeeiro Leucoptera coffeella (Guérin-Méneville). O Biológico, v.10, n.8, p.253-258, 1944.

FONSECA, J.P.da. O "bicho-mineiro" das folhas do cafeeiro e seu combate. O Biológico, v.15, n.9, p.167-172, 1949.

FUNDECITRUS. Ortézia cresce. Ação rápida é a melhor saída para combater a praga. Revista do Fundecitrus, v.29, n.119, p.15, 2003.

GALLO, D.; NAKANO, O.; SILVEIRA NETO, S.; CARVALHO, R.P.L.; BAPTISTA, G.C.; BERTI FILHO, E.; PARRA, J.R.P.; ZUCCHI, R.A.; ALVES, S.B.; VENDRAMIM, J.D.; MARCHINI, L.C.; LOPES, J.R.S.; OMOTO, C. Entomologia agrícola. Piracicaba: FEALQ, 2002. 920p. Biblioteca de Ciências Agrárias Luiz de Queiroz, v.10.

GARCIA, M.O. Utilização de fungos entomopatogênicos para o controle de Orthezia praelonga (Sternorryncha: Ortheziidae). Piracicaba, 2004. 57p. Dissertação (Mestrado) - Escola Superior de Agricultura "Luiz de Queiroz", Universidade de São Paulo. 
GARCIA, M.O.; SINISGALLI, D.L.; ALVES, S.B.; TAMAI, M.A.; LOPES, R.B. Seleção de isolados de fungos entomopatogênicos para o controle de Orthezia praelonga (STERNORRYNCHA: ORTHEZIIDAE). In: SIMPÓSIO INTERNACIONAL DE INICIAÇÃO CIENTÍFICA DA USP, 8., São Paulo, 2000. Anais. Piracicaba: ESALQ, 2000. p.23.

GAUNT, R. E. A mechanistic approach to yield loss assessment based on crop physiology. In: TENG, P. S. (Ed.). Crop loss assessment and pest management. St. Paul: The American Phytopathological Society, 1987. p.150-159.

GOMES, J.G.A. A "fumagina" e o piolho "Orthezia" da laranjeira e do limoeiro. Seleções Agrícolas, v.9, n.104, p.21-22, 1954.

GONÇALVEZ, C.R.; CASSINO, P.C.R. O problema da Orthezia praelonga na citricultura. In: ENCONTRO NACIONAL DE CITRICULTURA, 5., Rio de Janeiro, 1978. Anais. Rio de Janeiro: Pesagro, 1978. 5p.

GONTIJO, L.M; OLIVEIRA, I.R.; PICANÇO, M.C.; BARROS, E.C.; GUSMÃO, M.R. Plano de amostragem seqüencial do bicho mineiro com avaliação da presença/ausência em folhas do terço apical de cafeeiro em produção. In: SIMPÓSIO DE PESQUISA DOS CAFÉS DO BRASIL E WORKSHOP INTERNACIONAL DE CAFÉ E SAÚDE, 3.; Porto Seguro, 2003. Anais. Brasília: EMBRAPA Café, 2003. p.348-349.

GONZALES, R.H.; Biologia y ecologia y control de la escama de San Jose en Chile. Publicación en Ciências Agrícolas, n.9, p.37-42, 1981.

GOODMAN, R. N.; KIRÁLY, Z.; WOOD, K. R. The biochemistry and physiology of plant disease. Columbia: University of Missouri Press, 1986. 433p. 
GOODWIN, P. H. Effects of common bacterial blight on leaf photosynthesis of bean. Canadian Journal of Plant Pathology, v.14, p.203-206, 1992.

GORDON, T.R; DUNIWAY, J.M. Effects of powdery mildew infection on the efficiency of $\mathrm{CO}_{2}$ fixation and utilization by sugar beet leaves. Plant Physiology, v.69, p.139-142, 1982.

GRAVENA, S. Táticas de manejo integrado do bicho-mineiro do cafeeiro Perileucoptera coffeella (Guérin-Mèneville, 1842): Amostragem da praga e de seus inimigos naturais. Anais da Sociedade Entomológica do Brasil, v.12, n.2, p.273$281,1983$.

GRAVENA, S. Estratégias de manejo integrado do bicho-mineiro do cafeeiro Perileucoptera coffeella (Guérin-Mèneville, 1842). Anais da Sociedade Entomológica do Brasil, v.13, n.1, p.117-129, 1984.

GRAVENA, S. Manual prático de inspeção de pragas em citros. Jaboticabal: GRAVENA-ManEcol., 2002. 54p.

GUERREIRO FILHO, O;MAZZAFERA, P. Caffeine does not protect coffee against the leaf miner Perileucoptera coffeella. Journal of Chemical Ecology, v.26, n.6, p.1447-1464, 2000.

GUIRADO, N.; SAKAI, E.; AMBROSANO, E.J. Avaliação de efeito do óleo de nim extraído de sementes de Azadirachta indica no controle da cochonilha Ortézia em laranja Pêra. Revista de Agricultura, v.76, n.3, p.401-409, 2001.

HALL, D.O.; RAO, K.K. Photosynthesis: studies in biology. Cambridge: Cambridge University Press, 1994. 211p. 
HORSFALL, J.G.; BARRAT, R.W. An improved grading system for measuring plant diseases (abstr.) Phytopathology, v.35, p.655, 1945.

JAMES, W.C.; Assesment of plant diseases and losses. Annual Review of Phytopathology, v.12, p.27-48, 1974.

JOHNSON, K. B. Defoliation, disease and growth: a reply. Phytopathology, v.77, n.11, p.1495-1497, 1987.

KITAJIMA, K. Relative importance of photosynthetic traits and allocation patterns as cerrlates of seedling shade tolerance of tropical trees. Oecologia, v.98, n.3/4, p.419428, 1994.

KOGAN, M. Nota sobre as espécies do gênero Orthezia Bosq d'Antic, 1784, de importância econômica e que ocorrem no Brasil. Agronomia, v.22, p.134-144, 1964.

KOGAN, M. Integrated pest management: historical perspective and ctemporary development. Annual Review of Entomology, v.43, p.243-270, 1978.

KRIEDMANN, P.E. Some photosynthetic characteristics of citrus leaves. Australian Journal of Biological Sciences, v.21, n.5, p.895-905, 1968.

KRIEDMANN, P.E. Photosynthesis and transpiration as function of gaseous diffusive resistence in orange leaves. Physiologia Plantarum, v.24, n.2, p.218-225, 1971.

KUMAR, D.; TIESZEN, L.L. Photosynthesis in Coffeea arabica. Effects of light and temperature. Experimental Agriculture, v.16, n.1, p.13-19, 1980.

LARCHER, W. Stress bei Pflazen. Naturwissenschaften, v.74, p.158-167, 1987. 
LARCHER, W. Ecofisiologia vegetal. São Carlos: Rima, 2000.327p.

LEE, D.W. Simulating forest shade to study the development ecology of tropical plants: juvenile growth in three vines in India. Journal of Tropical Ecology, v.4, p.281292, 1988.

LEITE, B.; PASCHOLATI, S. F. Hospedeiro: alterações fisiológicas induzidas por fitopatógenos. In: BERGAMIN FILHO, A.; KIMATI, H.; AMORIM, L. (Ed.). Manual de fitopatologia: princípios e conceitos. 3.ed. São Paulo: Agronômica Ceres, 1995. v.1, cap. 21, p.393-416.

LICHTENTHALER, H.K. In vivo chlorophyll fluorescence as a tool for stress in plants. In: LICHTENTHALER, H.K. (Ed.). Applications of chlorophyll fluorescence., Kluwer, Dordrecht: Academic,1988. p.129-142.

LICHTENTHALER, H.K. Vegetation stress: an introduction to the stress concept in plants. Journal of Plant Physiology, v.148, p.4-14, 1996.

LIMA, A.F. Bioecologia de Orthezia praelonga Douglas, 1891 (Homóptera, Ortheziidae). Piracicaba, 1981. 126p. Dissertação (Mestrado) - Escola Superior de Agricultura "Luiz de Queiroz”, Universidade de São Paulo.

LIMA, A.F.; CASSINO, P.C.R.; RODRIGUES FILHO, I.L. Considerações sobre propagação e disseminação de Orthezia praelonga Douglas, 1891 (HomopteraOrtheziidae), em pomares cítricos no Estado do Rio de Janeiro. In: CONGRESSO BRASILEIRO DE ENTOMOLOGIA, 6., Campinas, 1980. Resumos. Campinas: Fundação Cargill, 1980. p.311. 
LONG, S.P.; HALLGREN, J.E. Measurement of $\mathrm{CO}_{2}$ assimilation by plants in the field and in the laboratory. In: HALL, D.O.; SCURLOCK, J.M.O.; BOLHÀRNORDENKAMPF, H.R.; LEEGOOD, R.C.; LONG, S.P. Photosynthesis and laboratory manual. London: Chapman \& Hall, 1993. p.129-167.

LOOMIS, R.S.; ADAMS, S.S. Integrative analysis of host-pathogen relations. Annual Review of Phytopathology, v.21, p.341-362, 1983.

LOOMIS, R.S.; RABBINGE, R.; OG, E. Explanatory models in crop physiology. Annual Review of Plant Physiology, v.30, p.339-367, 1979.

LOPES, D.B.; BERGER, R.D.; BERGAMIN FILHO, A. Absorção da área foliar sadia (HAA): uma nova abordagem para a quantificação de dano e para manejo integrado de doença. Summa Phytopatologica, v.20, p.143-151, 1994.

LORIMER, G.H.; ANDREWS, T.J. The $\mathrm{C}_{2}$ chem- and photorespiration carbon oxidation cycle. In: HATCH, M.D.; BOARDM, N.K. (Ed.) Photosynthesis: the biochemistry of plants, a comprehensive treatise. New York: Academic Press, 1981. v.8, p.330-375.

LOAYZA, R.M. Bioecologia e determinação do nível de controle de Selenaspidus articulatus (MORGAN, 1889) (HEMIPTERA: DIASPIDIDAE) em citros, Piracicaba, 1999, 110p. Tese (Doutorado) - Escola Superior de Agricultura "Luiz de Queiroz", Universidade de São Paulo.

LUCAS, J.A. Plant pathology and plant pathogens. 3.ed. Oxford: Blackwell Science, 1998. 274p.

LÜTTGE, U.; KLUGE, M.; BAUER, G. Botanique: traité fondamental. Trad. de V.A. Sieffert. Paris: Lavoisier, Tec \& Doc., 1996. cap.9, p.137-145: Les cytosomes. 
MADEIRA, A.C.; CLARK, J.A. The principles of resource capture in relation to necrotrophic infection. In: WALTERS, D.R.; SCHOLES, J.D.; BRYSON, R.J.; PAUL, N.D.; McROBERTS, N. (Ed.). Physiological responses of plants pathogens: aspects of applied biology. Warwick: AAB, 1995. p.19-31.

MIELE, A. Influência do sistema de condução na evolução dos açúcares redutores e da acidez total durante a maturação da uva: Relação com área foliar, radiação solar e fotossíntese. Revista Brasileira de Fisiologia Vegetal, v.1, n.1, p.31-40, 1989.

MONTEITH, J.L. Climate and the efficiency of crop production in Britain. Phylosophical Transactions of the Royal Society of London, v.281, p.277-294, 1997.

MONTEITH , J.L.; ELSTON, J. Performance and productivity in the field. In: DALE, J. E.; MILTHORPE, F. L. (Ed.) The growth and functioning of leaves. Cambridge: University Press, 1983. p.499-518.

MORENO, S.C.; OLIVEIRA, I.R.; PICANÇO, M.C.; GONTIJO, L.M.; GONRING, A.H.R.; FIDELIS, E.G.; BARROS, E.C. Plano de amostragem seqüencial do bicho mineiro com avaliação de presença/ausência em folhas do terço apical de cafeeiro em formação In: SIMPÓSIO DE PESQUISA DOS CAFÉS DO BRASIL E WORKSHOP INTERNACIONAL DE CAFÉ E SAÚDE, 3. Porto Seguro, 2003. Anais. Brasília: EMBRAPA Café, 2003. p.348.

MOSCARDI, F. Utilização de Baculovirus anticarsia para o controle da lagarta da soja, Anticarsia gemmatalis. Londrina: EMBRAPA-CNPSo, 1983. 21p. (Comunicado Técnico, 23). 
NANTES, J.F.D. Biologia e avaliação de danos de Perileucoptera coffeella (GuérinMéneville, 1842) (Lepidóptera - Lyonetiidae) em três variedades de café (Coffea arábica L.) Piracicaba, 1977. 73p. Dissertação (Mestrado) Escola Superior de Agricultura "Luiz de Queiroz", Universidade de São Paulo.

NANTES, IF.D.; PARRA, J.R.P. Avaliação de danos causados por Perileucoptera coffeella (Guérin-Mèneville, 1842) (Lepidoptera: Lyonetiidae), em três variedades de café (Coffea spp.). O Solo, v.69, n.2, p26-29, 1977.

NASCIMENTO, A.S. do. Ecologia da Orthezia praelonga Douglas, 1891 (Homóptera: Ortheziidae) na região de Cruz das Almas - BA. Cruz das Almas: Embrapa CNPMF, 1980. 4p. (Comunicado Técnico)

NASCIMENTO, A.S. do; MAGALHÃES, A.F.J.; SANCHES, N.F O caracol rajado traz benefícios para o pomar cítrico. Cruz das Almas - BA: Embrapa, CNPMF, 1993. 2p. (Embrapa/Cnpmf, Citros em Foco, 106).

NASCIMENTO, F.N. do; PERRUSO, J.C.; CASSINO, P.C.R. Novos hospedeiros de Orthezia praelonga Douglas, 1891 (Homóptera: Ortheziidae). Anais da Sociedade Entomológica do Brasil, v.22, n.1, p.213-215, 1993.

NEVES, A.D.; RIBEIRO, R.V.; OLIVEIRA, R.F.; PARRA, J.R.P. Determinação do nível de controle de Leucoptera coffeella (Guerin-Mènevilee,1842) com base em parâmetros fisiológicos In: CONGRESSO BRASILEIRO DE PESQUISAS CAFEEIRAS, 27., Uberaba, 2001, Resumos. Rio de Janeiro: PROCAFÉ, 2001. p.79.

NILSEN, E.T.; ORCUTT, D.M. The physiology of plants under stress: abiotic factors. New York: John Wiley, 1996. cap.11, p.445-485: High temperature and energy balance. 
OLIVEIRA, I.R. Amostragem de Leucoptera coffeella e das suas vespas predadoras no cafeeiro. Viçosa, 2003. 87p. Dissertação (Mestrado) - Universidade Federal de Viçosa.

O’TOOLE, J.C.; OZBUN, J.L.; WALLACE, D.H., Photosynthetic response to water stress in Phaseolus vulgaris L. Physiology Plantarum, v.40, p.11-114, 1977.

PARRA, J.R.P. Bioecologia de Perileucoptera coffeella (Guérin-Mèneville, 1842) (Lepidoptera - Lyonetiidae) em condições de campo. Piracicaba, 1975. 114p. Tese (Doutorado) - Escola Superior de Agricultura “Luiz de Queiroz”, Universidade de São Paulo.

PARRA, J.R.P. Biologia Comparada de Perileucoptera coffeella (Guérin-Mèneville, 1842) (Lepidoptera - Lyonetiidae), visando ao seu zoneamento ecológico no Estado de São Paulo. Piracicaba, 1981. 96p. Tese (Livre Docência) - Escola Superior de Agricultura "Luiz de Queiroz”, Universidade de São Paulo.

PARRA, J.R.P. Biologia comparada de Perileucoptera coffeella (Guérin-Méneville, 1842) (Lepidóptera, Lyonetiidae) visando ao seu zoneamento ecológico no Estado de São Paulo. Revista Brasileira de Entomologia, v.29, n.1, p.45-76, 1985.

PARRA, J.R.P.; NAKANO, O. Determinação do nível de dano econômico de Perileucoptera coffeella (Guérin-Méneville, 1842) (Lepidoptera - Lyonetiidae). In: CONGRESSO BRASILEIRO DE PESQUISAS CAFEEIRAS, 4., Caxambu, 1976. Resumos. Rio de Janeiro: IBC; GERCA, 1976, p.1.

PINNSCHMIDT,H.O.; TENG, P.S.; YOUNG, L. Methodology for quantifying rice yield effects of blast. In: ZEIGLER, R. S.; LEONG, S. A.; TENG, P. S. (Ed.). Rice blast disease. Wallingford: $\mathrm{CAB}$ Internartional, 1994. p.381-408. 
PONS, L.T.; BERGKOTTE, M.; Nitrogen allocation in response to partial shading of a plant: Possible mecanisms. Physiologia Plantarum, v.98, n.3, p.571-577, 1996.

PRATES, H.S. Piolho branco, a praga dos citros. Agroquímica Ciba-Geigy, n.12, p.1113, 1980.

PRATES, H.S. Ortézia, uma praga especial. Casa da Agricultura, v.9, p.16-19, 1987.

PRATES, H.S.; PINTO, W.B.S. Orthezia: uma praga potencial. Casa da Agricultura, v.9, n.6, p.16-19, 1987.

PRATES, H.S.; CESNIK, R.; ALVES, S.B. Controle da cochonilha Orthezia praelonga em citros. http://www.revistacoopercitrus.com.br/index.php/916? (10/jun/2002).

PROIETTI, P.; PALLIOTTI, A.; FAMIANI, F.; ANTOGNOZZI, E.; FERRANTI, F.; ANDREUTTI, R.; FRENGUELLI, G. Influence of leaf position, fruit anf light avaliability photosynthesis of two chesnut genotypes. Scientia Horticulturae, v.85, n.1/2, p.63-73, 2000.

PUZZI, D.; CAMARGO, A.P. Estudo sobre a possibilidade de adaptação climática da Orthezia praelonga Douglas, 1891, nos pomares de citros do Estado de São Paulo. O Biológico, v.29, n.5, p.81-85, 1963.

RAMIRO, D.A.; GUERREIRO FILHO, O.; VOLTAN, R.B.Q.; MATTHIESEN, S.C. Avaliação comparativa da anatomia foliar e do dano causado por Leucoptera coffeella em cafeeiros resistentes e susceptíveis ao inseto. In: SIMPÓSIO DE PESQUISA DOS CAFÉS DO BRASIL E WORKSHOP INTERNACIONAL DE CAFÉ E SAÚDE, 3., Porto Seguro, 2003. Anais. Brasília: EMBRAPA Café, 2003. p.326-327. 
RAMOS, J.; GRACE, J. The effects of shade on the gás exchange of seedlings of tropical trees from Mexico. Functional Ecology, v.4, n.5, p.667-677, 1990.

REIS JÚNIOR, R.. Interferência entre vespas e parasitóides de Leucoptera coffeella (Guérin-Meneville) (Lepidoptera : Lyonetiidae). Viçosa, 1999. 38p. Dissertação (Mestrado) - Universidade Federal de Viçosa.

REIS, P.R.; SOUSA, J.C. Manejo Integrado do bicho-mineiro do cafeeiro Perileucoptera coffeella (Guérin-Mèneville) (Lepidóptera: Lyonitiidae), e seu reflexo na produção de café. Anais da Sociedade Entomológica do Brasil, v.25, n.1. p.77-82, 1996

RIBEIRO, R.V. Influência da temperatura na fotossíntese de laranjeira pêra com clorose variegada dos citros. Piracicaba, 2002. 59p. Dissertação (Mestrado) - Escola Superior de Agricultura “Luiz de Queiroz”, Universidade de São Paulo.

RIBEIRO, R.V.; MACHADO, E.C.; OLIVEIRA, R.F. Early photosynthetic responses of sweet orange infected with Xylella fastidiosa. Physiological and Molecular Plant Pathology, v.62, p.167-173, 2003.

ROBBS, C.F. O "piolho branco" da laranjeira, uma ameaça a citricultura do Distrito Federal. Boletim do Campo, v.3, n.1, p.1-4, 1947.

ROSADO, J.F.; OLIVEIRA, I.R.; PICANÇO, M.C.; MORENO, S.C.; GUSMÃO, M.R.; SEMEÃO, A.A., Amostragem seqüencial do bicho-mineiro do cafeeiro em folhas do terço apical do dossel das plantas. In: SIMPÓSIO DE PESQUISA DOS CAFÉS DO BRASIL E WORKSHOP INTERNACIONAL DE CAFÉ E SAÚDE, 3., Porto Seguro, 2003. Anais. Brasília: EMBRAPA Café, 2003. p.324-325. 
ROSAMIGLIA, A.C. Caracterização morfológica e bioquímica de Colletotrichum gloeosporioides (PENZ.) PENZ. \& SACC; agente de controle da Orthezia praelonga Douglas, 1891. Rio Claro, 1998. 100p. Dissertação (Mestrado) - Instituto de Ciências Biológicas, Universidade Estadual Paulista "Júlio de Mesquita Filho".

SCHOLES, J.D. Photosynthesis: cellular and tissue aspects in diseased leaves. In: AYRES, P. G. (Ed.). Pest and pathogens: plant responses to foliar attack. Oxford: BIOS Scientific Publisher, 1992. p.85-106.

SCHOLES, J.D.; ROLFE, S.A. How do biotrophic pathogens affect the photosynthetic metabolism of their hosts? In: WALTERS, D.R.; SCHOLES, J.D.; BRYSON, R.J.; PAUL, N.D.; McROBERTS, N. (Ed.) Physiological responses of plants pathogens: Aspects of applied biology. Warwick: AAB, 1995. p.91-99.

SCHOLES, J.D.; LEE, P.J.; HORTON, P.; LEWIS, D.H. Invertase: understanding changes in the photosynthetic and carbohydrate metabolism of barley leaves infected with powdery mildew. New Phytologist, v.126, p.213-222, 1994.

SCHREIBER, U.; BERRY, J.A. Heat-induced changes of chlorophyll fluorescence in intact leaves correlated with damage of the photosynthetic apparatus. Planta, v.136, n.3, p.233-238, 1977.

SIEDOW, J. N., Public affairs. ASPP Newsletter, v.22, n.2, p.6-9, 1995.

SILVA-FILHO, R.; CASSINO, P.C.R.; VIEGAS, E.C.; PERRUSO, J.C. "Piolho Branco" Orthezia praelonga In: CASSINO, P.C.R.; RODRIGUES, W.C., Citricultura fluminense: principais pragas e seus inimigos naturais. Seropédica: EDUR, 2004. cap.4, p.27-40. 
SOUZA, N. DE. Comportamento fisiológico de cultivares de Coffea arábica L. submetidos a diferentes níveis de radiação solar. Lavras, 2001. 41p. Dissertação (Mestrado) - Universidade Federal de Lavras.

SQUIRE, G. R. The physiology of tropical crop production. Wallingford: CAB International, 1990. 236p.

STANGARLIN，J.R.; PASCHOLATI， S.F. atividades de ribulose 1,5 bifosfato carboxilase-oxigenase (rubisco), clorofilase, âa 1,3 glucanase e quitinase e conteúdo de clorofila em cultivares de feijoeiro (Phaseolus vulgaris) infectados com Uromyces appendiculatus. Summa Phytopathologica, v.26, p.34-42, 2000.

STONE, J.D.; PEDIGO, L.P. Development d economic-injury level of the green cloverworm on soybean in Iowa. Journal of Economic Entomology. v.65, p.197$201,1972$.

SUPLICY FILHO, N, SAMPAIO, AS; MYAZAKI, I. Considerações sobre o coccídeo Orthezia praelonga Douglas, 1891, importante praga da citricultura brasileira. O Biológico, v.49, n.1, p.19-24, 1983.

SZIRÁKI, I.; MUSTÁRDY, L.A.; FALUDI-DÁNIEL, A.; KIRÁLY, Z. Alterations in chloroplast ultrastructure and chorophyll content in rust infected pinto beans at different stages of disease development. Phytopathologist, v.74, p.77-84, 1984.

TAIZ, L.; ZEIGER, E. Fotossíntese: as reações luminosas. In: TAIZ, L.; ZEIGER, E. (Ed.). Fisiologia vegetal. Porto Alegre: Artmed, 2004. cap.7, p.139-172.

TAMAI, M.A.; LOPES, R.B.; ALVES, S.B. Manejo de pragas na floricultura. In: REUNIÃO ITINERANTE DE FITOSSANIDADE DO INSTITUTO BIOLÓGICO. Mogi das Cruzes, 2000. Anais. Mogi das Cruzes: Instituto Biológico, 2000. p.77-82. 
TAUNAY, A. E. História do café no Brasil Imperial, 1822-1872. Rio de Janeiro: Departamento Nacional do Café, 1943. v.5.

TEIXEIRA, M.A; BETTIOL, W; CESNIK, R. Patogenicidade do fungo Colletotrichum gloeosporioides, patógeno de Orthezia praelonga, para folhas, frutos e flores cítricas. Summa Phytopathologica, v.27, n.4, p.352-357, 2001.

TOZATTI, G.; GRAVENA, S. Fatores naturais de mortalidade de Perileucoptera coffeella, Guérin-Méneville, 1842 (Lepidóptera - Lyonetiidae), em café, Jaboticabal. Científica, v.16, n.2, p.179-187, 1988.

UEDA, Y.; NISHIHARA, S.; TOMITA, H.; ODA, Y. Photosynthetic response of Japanese rose species Rosa bracteata and Rosa rugosa to temperature and light. Scientia Horticulturae, v.84, n.3/4, p.365-371, 2000.

VASCONCELlOS, H.O.; CRUZ, C.A.; OLIVEIRA, A.M. Avaliação da capacidade de reprodução de Orthezia praelonga Douglas, 1891, em ambiente de laboratório e insetário. Anais da Sociedade Entomológica do Brasil, v.9, n.2, p.189-197, 1980.

VIEGAS, E.C.; SAMPAIO, H.N.; CARVALHO, P.O.L.; PERRUSO, J.C.; CASSINO, P.C.R. Controle alternativo de Orthezia praelonga Douglas, 1891 (Homóptera, Ortheziidae) em laboratório. In: CONGRESSO BRASILEIRO DE ENTOMOLOGIA, 15., Caxambu, 1995. Anais. Caxambu: Sociedade Entomológica do Brasil, 1995. p.333.

VILLACORTA, A.; TORNERO, M.T.T. Plano de amostragem seqüencial de dano causado por Perileucoptera coffeella no Paraná. Pesquisa Agropecuária Brasileira, v.17, n.9, p.1249-1260, 1982. 
VILLACORTA, A.; WILSON, L.T. Plano de amostragem seqüencial de presençaausência do dano causado pelo bicho mineiro do cafeeiro Leucoptera coffeella Guérin-Meneville. Anais da Sociedade Entomológica do Brasil, v.23, n.2, p.277284, 1994.

WAGGONER, P. E.; BERGER, R. D. Defoliation, disease and growth. Phytopathology, v.77, n.3, p.393-398, 1987.

WEBB, N; JENKINS, D. WinDias user manual. Cambridge: Delta-T Devices, 2000.85p.

ZADOKS, J. C.; SCHEIN, R. D. Epidemiology and plant disease management. New York: Oxford University Press, 1979. 427p.

ZUCCHI, R.A; A Taxonomia e o manejo de pragas. In: CROCOMO, W.B. Manejo integrado de pragas. Botucatu: UNESP; CETESB, 1990. cap.3, p.57-70. 